\title{
Pollen morphology and leaf anatomy of genus Globba in Thailand
}

\author{
Pornpun Kajornjit $^{\mathrm{a}}$, Surapon Saensouk ${ }^{\mathrm{b}, \mathrm{c}}$, Piyaporn Saensouk ${ }^{\mathrm{a}, \mathrm{b}, *}$ \\ a Department of Biology, Faculty of Science, Mahasarakham University, Mahasarakham 44150 Thailand \\ b Plant and Invertebrate Taxonomy and its Application Research Unit, Faculty of Science, \\ Mahasarakham University, Mahasarakham 44150 Thailand \\ c Walai Rukhavej Botanical Research Institute, Mahasarakham University, Mahasarakham 44150 Thailand
}

*Corresponding author, e-mail: pcornukaempferia@yahoo.com

Received 24 Nov 2017

Accepted 26 Jun 2018

\begin{abstract}
Pollen morphology was investigated in 22 taxa of the genus Globba (Zingiberaceae) from Thailand by means of light microscopy and scanning electron microscopy. The pollen grains of all taxa examined are monad, radially symmetric, apolar, and inaperturate. The sizes of the pollen grains are medium and large. The pollen grains have various shapes: oblate-spheroidal, spheroidal, and prolate-spheroidal. The exine ornamentation is short-echinate with psilate between the spine, short-echinate with rugulate between the spine, and psilate. The two types of spine apex are blunt and sharp. Palynological data has not been useful at the specific level. The leaf anatomy of 26 taxa was investigated by epidermal peeling and transverse sections of the leaves. The results indicate that the significant leaf anatomical characteristics for species identification are types of stomata, types of trichome, number of rows in intercostal regions, position of hypodermis, shape of midrib, types of vascular system, shape of midrib and leaf margins in transverse sections, and cell inclusion. Based on these anatomical characteristics, an identification key for Globba at the species level is given for the first time.
\end{abstract}

KEYWORDS: Zingiberaceae, palynology, leaf surface, scanning electron microscope

\section{INTRODUCTION}

The tribe Globbeae includes four genera, three of which, Globba, Gagnepainia, and Hemiorchis, are native to Thailand, while the fourth genus, Mantisia, has not yet been collected in Thailand. With over 100 species, Globba L. is the third largest genus of the Zingiberaceae (53 genera, $>1200$ species) ${ }^{1}$, with about 42 species reported in Thailand ${ }^{2}$. The members of the genus are small perennial herbs $(<1 \mathrm{~m}$ tall) with terminal inflorescences, although at least one species (G. racemosa Sm. $)^{1}$ can reach $3 \mathrm{~m}$. The floral features are unique: calyx turbinate to campanulate, 3-lobed to 3-dentate; corolla tube long, slender; labellum 2-lobed or entire, connate to the filament above the staminodes; lateral staminodes petaloid, free from labellum, elliptic, inserted at about same level as petals; and anther with or without lateral appendages. Flowers may be white, yellow, pink, orange or purple ${ }^{3}$. In Thailand, Globba is called 'dok khao phansa'. Inflorescence position, fruit shape, stamen length, and lateral staminode position are distinguishing characters for identification. These structures are found in certain seasons and some species are very similar in morphological characteristics. The current classification of the genus recognizes three subgenera, seven sections and two subsections based on the structure of the anther appendage ${ }^{1}$. In Thailand, we found all three subgenera, namely, subgenera Globba, Ceratanthera, and Mantisia (sect. Globba, Nudae, Ceratanthera, and Haplanthera, i.e., G. winitii, G. nuda, G. pendula, and G. racemosa, respectively). Globba species are distributed throughout tropical (and parts of subtropical) Asia, ranging from India to southern China, south and east to the Philippines and New Guinea ${ }^{4}$, with the centre of distribution in monsoonal Southeast Asia, especially Thailand $^{5}$ and Myanmar ${ }^{6}$. Most of the Globba species grow naturally in the different regions and their properties are important in traditional herbal medicine. In Thailand, three species of Globba were identified for ethnomedicine such as G. candida, G. obscura, and G. sp. for tuberculosis ${ }^{7}$. Three species were used as ornamental plants such as G. albiflora var. albiflora, G. laeta, G. cf. sherwood- 
iana, G. winitii, and G. williamsiana. Five species were used as ornamental plants such as G. albiflora var. albiflora, G. laeta, G. cf. sherwoodiana, G. winitii, and $G$. williamsiana. Some Globba species were used as ritual plants especially $G$. barthei, G. laeta, G. marantina, and G. schomburgkii ${ }^{8}$. They have cultural importance in Thailand, for example, at the 'Tak Bat Dok Mai' festival in Saraburi Province.

Pollen morphology is important for studying plant taxonomy in the family Zingiberaceae. The pollen morphology of Zingiberaceae has been studied by various researchers. They have used many characteristics of the pollen grains for identifying the species of plants, i.e., shape, size, symmetry, and polar aperture ${ }^{9-15}$, and for classification at the generic and sectional levels ${ }^{16}$. The pollen morphology of the genus Globba has been studied by various researchers ${ }^{17-19}$. They found that the pollen grains are non-aperturate and exine sculpture is short-spinate. Kaewsri and Paisooksantivatana ${ }^{20}$ studied the pollen grains of 14 representatives of Thai Amomum using a scanning electron microscope (SEM). The result revealed that pollen grains are spherical to subspherical, inaperturate; exine sculpture is psilate and echinate. Although exine sculpturing can be used to divide the species into two groups, it is less useful for subgeneric classification. Syamsuardi ${ }^{21}$ studied the pollen morphology of 9 taxa of Globba (G. leucantha, G. patens, G. variabilis, G. hasseltii, G. fecunda, G. atrosanguinea, G. aurantiaca, G. multifolia, and G. paniculata) that were collected from various fields in the regions of West Sumatra. Four diagnostic characteristics (pollen types, shapes, apertures, and ornamentations) were examined and photographed by SEM. Jones and Pearce ${ }^{22}$ studied the pollen morphology of G. propinqua. The result showed that the pollen grains are inaperturate, spheroidal and the exine sculpture is granulate with gemmae. The size of the pollen grains is $29-42 \mu \mathrm{m}$ in equatorial view. The pollen grains of Zingiberaceae are generally not resistant to acetolysis. The wall is composed of a very thin exine and a thick intine.

Leaf anatomical characters of some Globba species were reported by Tomlinson ${ }^{23,24}$, who studied the anatomy of 41 species from 20 genera of Zingiberaceae, i.e., subfamilies Costoideae and Zingiberoideae (tribes Globbeae, Hedychieae, and Alpinieae). The leaf anatomies of two species of Globba (G. bulbifera and G. winitii) were studied. The position of the hypodermis, large solitary bodies of crystalline material occurring in hypodermal cells in the leaf blade (silica sand in the lamina), was confined to the parenchyma of the bundle sheath; trichome presence or absence on the margin of the leaf can be used for species identification. The leaf anatomy of 22 Alpinia species from China were studied by Hussin ${ }^{25}$. The results showed that there are interspecific variations in the structure of the midrib and petiole, which can be used for species identification. Lakoet ${ }^{26}$ investigated leaf epidermal peels and transverse sections of roots, rhizomes, aerial stems, and leaves that consisted of the blades, margins, midribs, petioles, and leaf sheaths of 4 tribes, 9 genera, and 39 species of Zingiberaceae in Phu Phan National Park, Thailand. The leaf anatomies of 6 species of Globba (G. annamensis, G. bartheii, G. laeta, G. marantina, G. panicoides, and G. winitii) were studied. Inclusions in the costal regions on both leaf surfaces, simple unicellular hairs on both leaf surfaces, hypodermis, and stomata on both leaf surfaces, shape in transverse section, and type of cell in the leaf margins, shape and vascular bundle systems in cross section of the midrib, middle parts, and lateral parts of the leaf sheaths can be used for species identification. Saensouk ${ }^{11}$ studied the leaf anatomy of 20 taxa of the genus Alpinia in Thailand. The leaf anatomy of the genus can be classified using the distribution of stomata, trichomes, shape of subsidiary cells, silica body, silica sand, tannin, and solitary crystals. Saensouk ${ }^{13}$ studied the comparative anatomy of three species of Cornukaempferia from northeastern Thailand. The presence of stomata, trichome, papillae, hypodermis, shape of leaf margin, and type of vascular system for both species of Cornukaempferia were highly similar and cannot be used for species identification, due to the plants in the genus Globba being quite similar in morphology. Furthermore, some characters used for species identification are floral parts that cannot be found all the year. Anatomical data are often extremely useful in solving problems of relationships because they can often suggest with greater confidence the homologies of morphological character states, and they can help in the interpretation of evolutionary directionality ${ }^{27}$. For pollen morphology study, it is well known that pollen features have a great taxonomic value, and they have been used in the classification of different genera ${ }^{28,29}$ and closely related Zingiberaceae taxa. However, most species of this genus in Thailand have not had their pollen morphology and leaf anatomy studied. The aims of the present paper are to describe the comparative pollen morphology and leaf anatomy of Globba in Thailand and to provide useful characteristics in relation to taxonomy. 


\section{MATERIALS AND METHODS}

\section{Plant collection and plant materials}

The plant species were surveyed and specimens were collected from fields in Thailand during MayAug 2013 and May-Aug 2016. This study is also a review of the literature dealing with Globba and related genera distributed in Thailand. The herbarium specimens studied were from BK, BKF, QBG, PSU, and Department of Biology Herbarium Chiang Mai University. Field collections and flowering period observations of Globba were made in Thailand. The specimens examined were annotated using taxonomic methods. Specimens were pressed and fixed in $70 \%$ ethanol. Living specimens of the genus Globba were collected from various locations in Thai forests, then transplanted into pots at Mahasarakham University Nursery. The specimens were collected and deposited as reference specimens in the Mahasarakham University Herbarium. Specimens were studied palynologically and leaf anatomical characters was obtained from spirit specimens.

\section{Palynological studies}

The anthers of 22 Thai Globba were stored in 70\% ethanol. Pollen grains of the genus Globba in Thailand were examined by a light microscope (LM) and scanning electron microscope (SEM). Samples were dehydrated using an alcohol series of $70 \%, 80 \%$, $95 \%$, and $100 \%$. For LM studies, pollen grains were mounted in silicone oil and sealed with paraffin. At least 30 pollen grains per sample were measured for the diameter $(\mu \mathrm{m})$ of the pollen in the polar axis and equatorial axis. Data analyses were performed using the means and standard errors. Shapes were described according to the $\mathrm{P} / \mathrm{E}$ ratio (the length of the polar axis to the equatorial axis). The pollen shape and size classification followed Erdtman ${ }^{30}$. Photographs were taken using an Olympus BX50 light microscope. For SEM studies, pollen grains in absolute alcohol were dried on aluminium stubs with double-sided cellophane tape. Samples were sputter-coated with gold-palladium, examined, and then photographs were taken with a JEOL: JSM 8460LV SEM to determine the exine sculpturing and aperture. The terminology adopted to describe the palynological characters was according to Punt ${ }^{31}$.

\section{Leaf anatomical studies}

The leaves of 26 taxa of Globba species were taken from spirit specimens. They were fixed in $70 \%$ alcohol or $70 \%$ FAA, dehydrated in a tertiary butyl alcohol series, sectioned on a rotary microtome at 5-10 $\mu \mathrm{m}$ thickness and stained in safranin and Fast green. Transverse sections were made from blades, margins, and midribs. For epidermal peeling studies, samples were prepared by mechanical scraping between the midrib and margin of the lamina, stained with $1 \%$ safranin in water and then mounted in DePeX ${ }^{32}$. Photographs were taken with the aid of an Olympus BX50 light microscopy. All specimens examined and slide collections are kept at the Mahasarakham University Herbarium.

\section{RESULTS}

\section{Pollen morphology}

The pollen of 22 taxa of the genus Globba in Thailand is monad, radial symmetry, apolar, and inaperturate (Table 1, Figs. 1-3). The pollen shape can be divided into 3 types as follows: oblate-spheroidal, including $G$. adhaerens (violaceus bract), G. bicolor, G. cambodgensis, G. laeta, G. panicoides, G. williamsiana, and $G$. winitii; spheroidal, including G. albiflora var. albiflora, G. annamensis, G. marantina, G. nuda, G. praecox, G. racemosa, G. sessiliflora, G. sherwoodiana, and G. xantholeuca; and prolatespheroidal, including G. adhaerens (albus bract), G. albiflora var. aurea, G. globulifera, G. pendula, $G$. schomburgkii, and $G$. siamensis. The pollen grains of most Thai Globba are medium sized except in G. adhaerens (albus bract), G. annamensis, G. bicolor, and $G$. panicoides, which are large sized. The wall thickness of the pollen varies from $6.4 \pm 2.2 \mu \mathrm{m}$ (G. winitii) to $20.0 \pm 7.5 \mu \mathrm{m}$ (G. laeta). The length of the spine varies from $0.4 \pm 0.1 \mu \mathrm{m}$ in $G$. bicolor to $1.8 \pm 0.2 \mu \mathrm{m}$ in $G$. racemosa. The width of the spine base varies from $0.6 \pm 0.1 \mu \mathrm{m}$ in $G$. nuda to $2.8 \pm 0.8 \mu \mathrm{m}$ in $G$. laeta. The spine apex characteristic can be divided into two groups as follows: sharp apex, including G. adhaerens (albus bract), G. albiflora var. aurea, G. pendula, G. praecox, G. racemosa, $G$. sessiliflora, and $G$. williamsiana; and blunt apex, including G. adhaerens (violaceus bract) G. albiflora var. albiflora, G. annamensis, G. bicolor, G. cambodgensis, G. globulifera, G. laeta, G. marantina, G. nuda, G. schomburgkii, G. sherwoodiana, G. siamensis, G. winitii, and G. xantholeuca. The distance between the spines ranges from $0.8 \pm 0.2 \mu \mathrm{m}$ in G. globulifera to $4.5 \pm 1.7 \mu \mathrm{m}$ in $G$. schomburgkii. The minimum spine density $\left(0.01 \pm 0.00\right.$ per $\left.\mu \mathrm{m}^{2}\right)$ is observed in $G$. laeta and $G$. williamsiana and the maximum spine density $\left(0.06 \pm 0.03\right.$ per $\left.\mu \mathrm{m}^{2}\right)$ is observed in G. albiflora var. albiflora. The exine sculpturing can be divided into three types as fol- 
Table 1 Pollen morphology data of Thai Globba*

\begin{tabular}{|c|c|c|c|c|c|c|c|c|c|c|c|c|c|}
\hline $\operatorname{Taxa}^{\dagger}$ & $\begin{array}{c}\mathrm{P} \\
(\mu \mathrm{m})\end{array}$ & $\begin{array}{c}E \\
(\mu \mathrm{m})\end{array}$ & $\begin{array}{l}\mathrm{P} / \mathrm{E} \\
\text { ratio }\end{array}$ & Shape ${ }^{*}$ & Size $^{+}$ & $\begin{array}{c}\mathrm{SL} \\
(\mu \mathrm{m})\end{array}$ & $\begin{array}{c}\text { SW } \\
(\mu \mathrm{m})\end{array}$ & SA & $\begin{array}{l}\text { WT } \\
(\mu \mathrm{m})\end{array}$ & $\begin{array}{c}\text { DS } \\
(\mu \mathrm{m})\end{array}$ & $\begin{array}{c}\text { SD } \\
\left(\text { per } \mu \mathrm{m}^{2}\right)\end{array}$ & ES & $\begin{array}{c}\text { Collect } \\
\text { No. }\end{array}$ \\
\hline 1 & $43.3 \pm 3.8$ & $43.7 \pm 3.3$ & 0.99 & OS & M & $0.9 \pm 0.1$ & $1.1 \pm 0.1$ & blunt & $16.8 \pm 3.4$ & $3.7 \pm 1.0$ & $0.02 \pm 0.01$ & SEP & K.41 \\
\hline 2 & $62.9 \pm 3.9$ & $61.5 \pm 4.2$ & 1.02 & PS & $\mathrm{L}$ & $1.4 \pm 0.2$ & $1.6 \pm 0.2$ & sharp & $15.3 \pm 1.5$ & $4.2 \pm 1.2$ & $0.04 \pm 0.01$ & SEP & K.34 \\
\hline 3 & $49.4 \pm 4.1$ & $49.0 \pm 3.4$ & 1.00 & S & M & $0.5 \pm 0.1$ & $0.6 \pm 0.1$ & blunt & $9.5 \pm 2.2$ & $1.1 \pm 0.2$ & $0.06 \pm 0.03$ & SEP & K.40 \\
\hline 4 & $47.7 \pm 2.7$ & $40.4 \pm 8.8$ & 1.05 & PS & M & $0.8 \pm 0.1$ & $0.8 \pm 0.1$ & sharp & $11.2 \pm 3.4$ & $2.5 \pm 0.6$ & $0.03 \pm 0.02$ & SER & K.60 \\
\hline 5 & $51.8 \pm 2.9$ & $51.5 \pm 2.2$ & 1.00 & $\mathrm{~S}$ & $\mathrm{~L}$ & $0.5 \pm 0.1$ & $0.9 \pm 0.3$ & blunt & $10.4 \pm 2.2$ & $3.1 \pm 0.6$ & $0.02 \pm 0.01$ & SEP & K.46 \\
\hline 6 & $50.6 \pm 3.2$ & $51.3 \pm 2.8$ & 0.98 & OS & $\mathrm{L}$ & $0.4 \pm 0.1$ & $0.7 \pm 0.1$ & blunt & $13.6 \pm 2.2$ & $3.2 \pm 0.6$ & $0.02 \pm 0.00$ & SER & K.42 \\
\hline 7 & $49.0 \pm 2.4$ & $50.6 \pm 2.1$ & 0.97 & OS & M & $1.2 \pm 0.2$ & $0.7 \pm 0.1$ & blunt & $11.2 \pm 1.8$ & $3.4 \pm 0.7$ & $0.03 \pm 0.00$ & SEP & K.55 \\
\hline 8 & $9.3 \pm 2.2$ & $38.5 \pm 1.9$ & 1.02 & PS & M & $0.5 \pm 0.0$ & $0.8 \pm 0.2$ & blunt & $11.2 \pm 3.4$ & $0.8 \pm 0.2$ & $0.04 \pm 0.01$ & SER & K.76 \\
\hline 9 & $46.8 \pm 5.7$ & $47.1 \pm 5.0$ & 0.99 & OS & M & $1.6 \pm 0.2$ & $2.8 \pm 0.8$ & blunt & $20.0 \pm 7.5$ & $2.4 \pm 0.6$ & $0.01 \pm 0.00$ & SER & K.37 \\
\hline 10 & $49.5 \pm 2.1$ & $49.1 \pm 2.0$ & 1.00 & S & M & $1.1 \pm 0.1$ & $2.1 \pm 0.1$ & blunt & $8.8 \pm 3.4$ & $1.0 \pm 0.2$ & $0.03 \pm 0.01$ & SEP & K.44 \\
\hline 11 & $37.3 \pm 1.8$ & $37.1 \pm 1.9$ & 1.00 & $S$ & M & $0.7 \pm 0.1$ & $0.6 \pm 0.1$ & blunt & $16.5 \pm 3.4$ & $1.8 \pm 0.4$ & $0.03 \pm 0.01$ & SER & K.65 \\
\hline 12 & $51.1 \pm 4.3$ & $51.9 \pm 2.5$ & 0.98 & OS & $\mathrm{L}$ & - & - & - & $7.2 \pm 1.8$ & - & - & psl & K.47 \\
\hline 13 & $46.1 \pm 6.7$ & $45.6 \pm 3.6$ & 1.01 & PS & $\mathrm{M}$ & $1.2 \pm 0.3$ & $1.3 \pm 0.2$ & sharp & $12.8 \pm 1.5$ & $2.2 \pm 0.4$ & $0.04 \pm 0.02$ & SEP & K.68 \\
\hline 14 & $39.4 \pm 1.9$ & $39.4 \pm 1.9$ & 1.00 & $\mathrm{~S}$ & M & $0.5 \pm 0.1$ & $0.6 \pm 0.2$ & sharp & $9.7 \pm 2.2$ & $1.8 \pm 0.4$ & $0.02 \pm 0.01$ & SEP & K.80 \\
\hline 15 & $49.3 \pm 3.5$ & $49.3 \pm 2.9$ & 1.00 & S & M & $1.8 \pm 0.2$ & $2.3 \pm 0.3$ & sharp & $10.4 \pm 2.2$ & $1.9 \pm 0.7$ & $0.02 \pm 0.00$ & SEP & К.90 \\
\hline 16 & $46.8 \pm 3.5$ & $46.1 \pm 4.3$ & 1.01 & PS & M & $0.5 \pm 0.1$ & $1.2 \pm 0.2$ & blunt & $12.8 \pm 1.8$ & $4.5 \pm 1.7$ & $0.01 \pm 0.01$ & SEP & K.36 \\
\hline 17 & $36.1 \pm 2.4$ & $36.0 \pm 2.4$ & 1.00 & $\mathrm{~S}$ & M & $1.0 \pm 0.1$ & $1.2 \pm 0.1$ & sharp & $9.8 \pm 2.2$ & $4.0 \pm 0.9$ & $0.01 \pm 0.01$ & SEP & К.72 \\
\hline 18 & $40.4 \pm 8.9$ & $40.1 \pm 9.0$ & 1.00 & $S$ & M & $0.8 \pm 0.1$ & $1.2 \pm 0.1$ & blunt & $13.6 \pm 2.2$ & $2.9 \pm 0.7$ & $0.03 \pm 0.02$ & SER & K.85 \\
\hline 19 & $45.2 \pm 2.1$ & $44.1 \pm 2.3$ & 1.02 & PS & M & $0.8 \pm 0.1$ & $1.8 \pm 0.2$ & blunt & $10.4 \pm 2.3$ & $3.8 \pm 0.3$ & $0.02 \pm 0.01$ & SEP & К.39 \\
\hline 20 & $48.0 \pm 2.6$ & $49.2 \pm 2.2$ & 0.98 & OS & M & $1.1 \pm 0.1$ & $1.3 \pm 0.2$ & sharp & $12.2 \pm 2.0$ & $2.3 \pm 0.4$ & $0.01 \pm 0.00$ & SEP & K.83 \\
\hline 21 & $46.3 \pm 3.5$ & $46.9 \pm 3.0$ & 0.98 & OS & M & $1.3 \pm 0.2$ & $1.3 \pm 0.1$ & blunt & $6.4 \pm 2.2$ & $2.8 \pm 0.4$ & $0.03 \pm 0.02$ & SER & K.35 \\
\hline 22 & $47.3 \pm 3.4$ & $47.3 \pm 3.9$ & 1.00 & $S$ & M & $0.9 \pm 0.1$ & $0.9 \pm 0.3$ & blunt & $9.6 \pm 2.2$ & $3.1 \pm 0.7$ & $0.02 \pm 0.01$ & SER & K.81 \\
\hline
\end{tabular}

$* \mathrm{P}=$ polar axis, $\mathrm{E}=$ equatorial axis, $\mathrm{SL}=$ spine length, $\mathrm{SW}=$ spine width, $\mathrm{SA}=$ spine apex, $\mathrm{WT}=$ wall thickness, $\mathrm{DS}=$ distance between the spine, $\mathrm{SD}=$ spine density, $\mathrm{ES}=$ exine sculpture.

$\dagger 1=$ G. adhaerens Gagnep. (violaceus bract), $2=$ G. adhaerens Gagnep. (albus bract), $3=$ G. albiflora var. albiflora, $4=G$. albiflora var. aurea, $5=G$. annamensis Gagnep., $6=G$. bicolor Gagnep., $7=G$. cambodgensis Gagnep., $8=$ G. globulifera Gagnep., $9=$ G. laeta K.Larsen., $10=$ G. marantina, $11=$ G. nuda K.Larsen., $12=$ G. panicoides Miq., $13=$ G. pendula Roxb., $14=$ G. praecox K.J.Williams \& Paisooks., $15=$ G. racemosa Sm., $16=$ G. schomburgkii Hook.f., $17=$ G. sessiliflora Sims, $18=$ G. sherwoodiana W.J.Kress \& V.Gowda, $19=$ G. siamensis (Hemsl.) Hemsl., $20=$ G. williamsiana M.F.Newman, $21=G$. winitii C.H.Wright, $22=G$. xantholeuca Craib.

$*$ OS $=$ oblate-spheroidal, PS $=$ prolate-spheroidal, $\mathrm{S}=$ spheroidal, $\mathrm{L}=$ large, $\mathrm{M}=$ medium.

${ }^{\#}$ K. = Kajornjit.

lows: short-echinate with psilate between the spine (Fig. 3:a-c, e, g, j, m-q, s, and t), short-echinate with rugulate between the spine (Fig. 3:d, f, h, i, k, r, $\mathrm{u}$, and $\mathrm{v}$ ), and psilate was found only in G. panicoides (Fig. 31).

\section{Leaf anatomical studies}

The results of the leaf anatomy showed some variations and similarities in the leaf anatomical characteristics of the Globba species studied. A summary of the leaf anatomical characteristics observed in this study is presented in Tables 2-5.

\section{Leaf surface}

The epidermal cells on both surfaces of all the Globba species are four to seven-sided (Fig. 4). Most of the stomata on both surfaces are tetracytic (Tables 2 and 3 and Fig. 4a), and guard cells are surrounded by four subsidiary cells except for G. albiflora var. albiflora, G. annamensis, G. bicolor, G. cambodgensis, G. laeta, G. marantina, G. nuda, G. purpurascens, G. sessiliflora, G. sherwoodiana, G. siamensis, G. williamsiana, and G. winitii, which have a combination of tetracytic and pentacytic stomata on the adaxial surface. On the adaxial surface in G. praecox and G. racemosa there is a combination of tetracytic, pentacytic (Fig. 4b) and rarely hexacytic (Fig. 4c). In addition, in G. adhaerens (albus bract), G. albiflora var. albiflora, G. albiflora var. aurea, G. pendula, and G. praecox there is a combination of tetracytic and pentacytic stomata on the abaxial surface. Stomata are distributed at random on both sides with fewer stomata distributed in rows near veins. The stomata develop on both surfaces but are infrequent on the adaxial surface. The density of stomata for all species is different for every leaf sample in each species (Tables 2 and 3 ). The width of the epidermal cells on the adaxial side varies from $47.0 \pm 4.2 \mu \mathrm{m}$ in G. schomburgkii to $91.5 \pm 7.4 \mu \mathrm{m}$ in G. sessiliflora (Table 2), while the width of the epidermal cells on the abaxial side varies from $33.5 \pm 2.1 \mu \mathrm{m}$ in $G$. nuda to $66 \pm 12 \mu \mathrm{m}$ in G. williamsiana (Table 3). Epidermal cells in the intercostal regions on the adaxial surface varies from 6 rows (G. adhaerens (albus bract), G. albiflora var. aurea, G. marantina, G. nuda) to 26 rows 


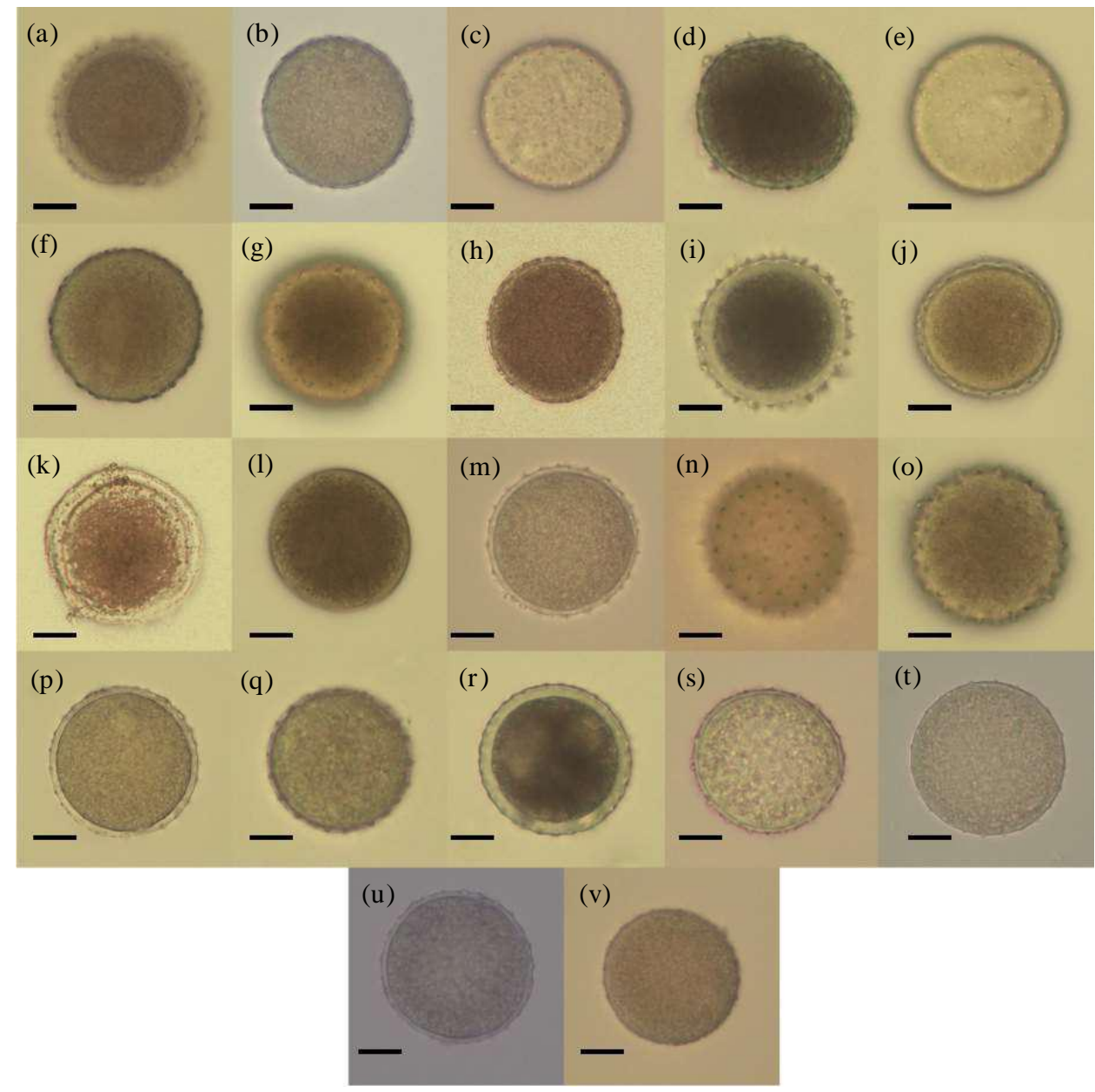

Fig. 1 Light microscopy micrographs of pollen grains. (a) G. adhaerens (violaceus bract), (b) G. adhaerens (albus bract), (c) G. albiflora var. albiflora, (d) G. albiflora var. aurea, (e) G. annamensis, (f) G. bicolor, (g) G. cambodgensis, (h) G. globulifera, (i) G. laeta, (j) G. marantina, (k) G. nuda, (l) G. panicoides, (m) G. pendula, (n) G. praecox, (o) G. racemosa, (p) G. schomburgkii, (q) G. sessiliflora, (r) G. sherwoodiana, (s) G. siamensis, (t) G. williamsiana, (u) G. winitii, (v) G. xantholeuca. Scale bars $=20 \mu \mathrm{m}$.

(G. praecox), whereas the epidermal cells in the intercostal regions on the abaxial surface are greatest in G. winitii (18 rows) and the lowest in G. albiflora var. aurea and G. panicoides (5 rows) (Fig. 4d, e). The greatest length of the guard cell is found in G. laeta $(39.6 \pm 1.7 \mu \mathrm{m})$ and the lowest in $G$. annamensis $(27.0 \pm 2.1 \mu \mathrm{m})$ (Table 2$)$. The length of the guard cells on the abaxial surface is greatest in G. racemosa $(49.5 \pm 4.1 \mu \mathrm{m})$ and the lowest in G. praecox $(25.5 \pm 2.0 \mu \mathrm{m})$ (Table 3). The shape of the subsidiary cells is found to be dome-shaped on both surfaces. The density of the stomata on the adaxial surface ranges from $2 \pm 1$ per $\mathrm{mm}^{2}$ in G. reflexa to $67 \pm 4$ per $\mathrm{mm}^{2}$ in $G$. marantina, while the density of stomata on the abaxial surface varies from $88 \pm 8$ per $\mathrm{mm}^{2}$ in $G$. racemosa to $273 \pm 15$ per $\mathrm{mm}^{2}$ in G. reflexa. Trichomes are present on both surfaces, except in G. albiflora var. albiflora, G. albiflora var. aurea, G. globulifera, G. laeta and G. nuda, in which trichomes are not found on both surfaces. Some species have trichomes that are found only on the adaxial surface, such as G. marantina, G. sherwoodiana, G. williamsiana, and G. xantholeuca. Most species have trichomes only on the abaxial surface, i.e., G. cambodgensis, G. laeta, G. panicoides, G. praecox, G. purpurascens, $G$. racemosa, and $G$. reflexa. Four types of trichomes were recorded here.

Type 1: short, simple unicellular trichomes (length of trichomes $<400 \mu \mathrm{m}$ ) are found on adaxial surface, which includes $G$. adhaerens (violaceus bract), 


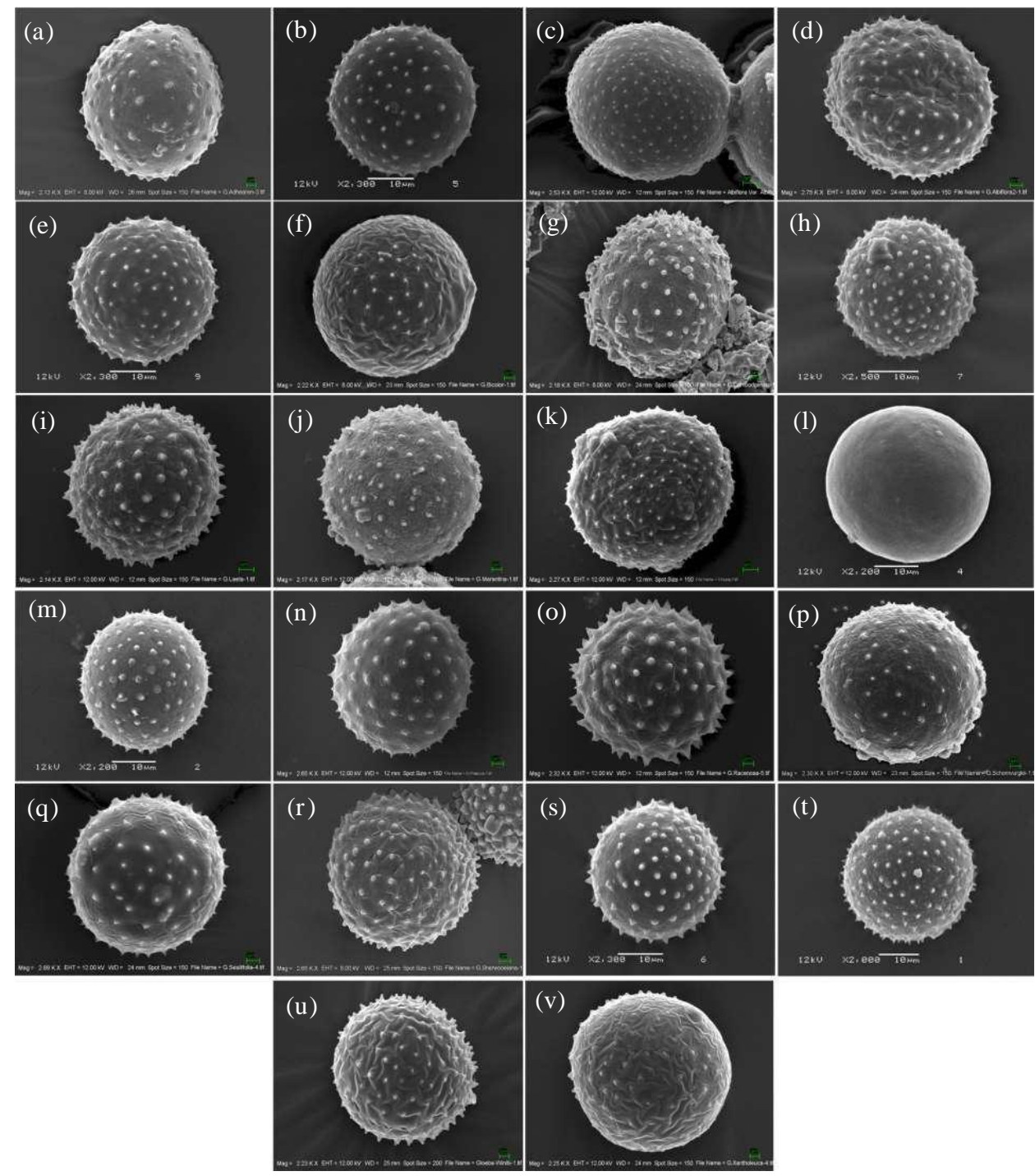

Fig. 2 SEM micrographs of pollen grains. (a) G. adhaerens (violaceus bract), (b) G. adhaerens (albus bract), (c) G. albiflora var. albiflora, (d) G. albiflora var. aurea, (e) G. annamensis, (f) G. bicolor, (g) G. cambodgensis, (h) G. globulifera, (i) G. laeta, (j) G. marantina, (k) G. nuda, (l) G. panicoides, (m) G. pendula, (n) G. praecox, (o) G. racemosa, (p) G. schomburgkii, (q) G. sessiliflora, (r) G. sherwoodiana, (s) G. siamensis, (t) G. williamsiana, (u) G. winitii, (v) G. xantholeuca. (a, d, f, j, n, o-r, u, v) scale bars $=2 \mu \mathrm{m}$; (c, g, i, k) scale bars $=3 \mu \mathrm{m}$; (b, h) scale bars $=5 \mu \mathrm{m} ;(\mathrm{e}, 1, \mathrm{~m}, \mathrm{~s}, \mathrm{t})$ scale bars $=10 \mu \mathrm{m}$.

G. annamensis, G. candida, G. marantina, G. pendula, G. schomburgkii, G. sessiliflora, and G. winitii, while for the abaxial surface they are found in G. adhaerens (violaceus bract), G. bicolor, G. cambodgensis, G. candida, G. laeta, G. panicoides, G. pendula, G. praecox, G. racemosa, G. schomburgkii, and G. sessiliflora (Fig. 4f).

Type 2: long, simple unicellular trichomes (length of trichomes $>400 \mu \mathrm{m}$ ) are found on adaxial sur- face, which includes $G$. aff. winitii, G. marantina, and $G$. siamensis, while for the abaxial surface they are found in G. aff. winitii, G. annamensis, G. siamensis, and G. winitii (Fig. 4g).

Type 3: long, biseriate trichomes (length of trichomes $>400 \mu \mathrm{m}$ ) are found on adaxial surface, which includes $G$. adhaerens (albus bract) and $G$. aff. winitii, while for the abaxial surface they are found in G. adhaerens (albus bract), G. aff. winitii, 

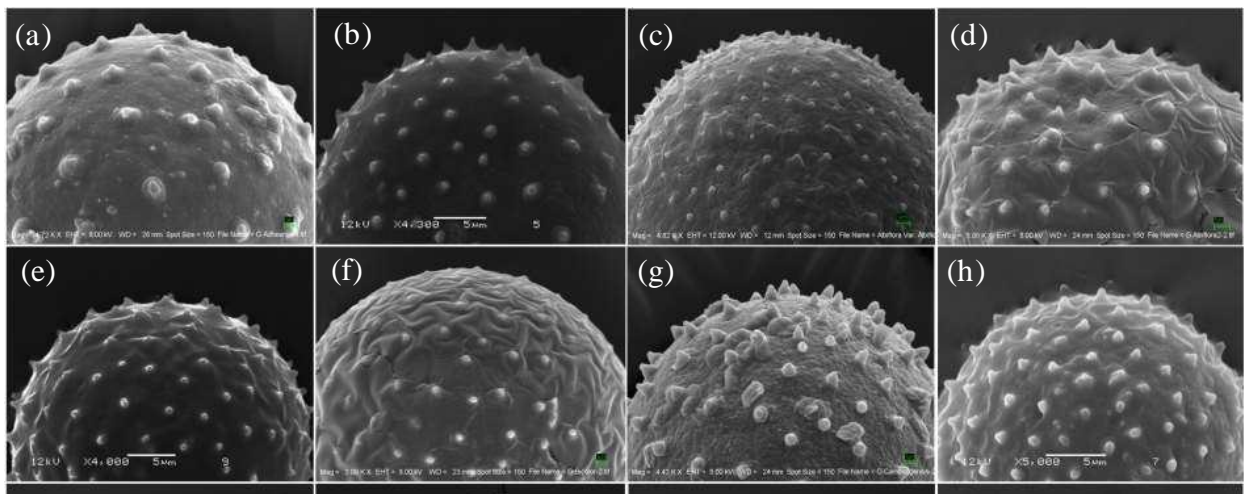

(h)
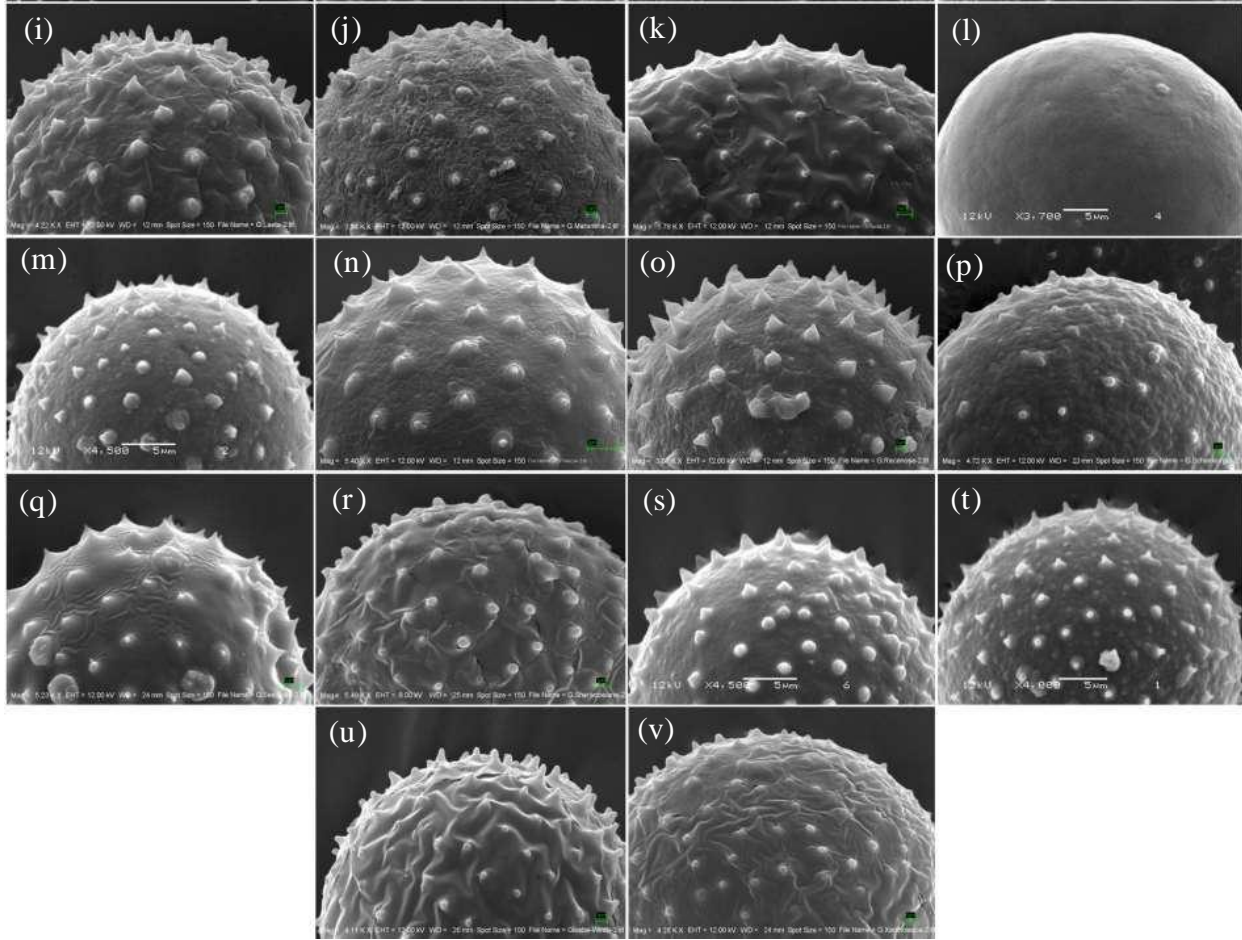

Fig. 3 Exine ornamentation of pollen grains. (a) G. adhaerens (violaceus bract), (b) G. adhaerens (albus bract), (c) G. albiflora var. albiflora, (d) G. albiflora var. aurea, (e) G. annamensis, (f) G. bicolor, (g) G. cambodgensis, (h) G. globulifera, (i) G. laeta, (j) G. marantina, (k) G. nuda, (l) G. panicoides, (m) G. pendula, (n) G. praecox, (o) G. racemosa, (p) G. schomburgkii, (q) G. sessiliflora, (r) G. sherwoodiana, (s) G. siamensis, (t) G. williamsiana, (u) G. winitii, (v) G. xantholeuca. (a, c, d, f, g, i, j, k, o-r, u, v) scale bars $=1 \mu \mathrm{m}$; (n) scale bar $=3 \mu \mathrm{m}$; (b, e, h, l, m, $\mathrm{s}$, t) scale bars $=5 \mu \mathrm{m}$.

\section{G. siamensis, and G. winitii (Fig. 4h).}

Type 4: glandular trichomes are found on adaxial surface in G. bicolor and G. cambodgensis while for the abaxial surface they are found in G. cambodgensis, G. candida, G. praecox, G. purpurascens, G. racemosa, G. reflexa, G. sherwoodiana, G. williamsiana, G. winitii and G. xantholeuca (Fig. 4b).

The density of trichomes is quite high $(219 \pm 6$ per $\mathrm{mm}^{2}$ ) on the abaxial surface when compared to the adaxial surface $\left(54 \pm 7\right.$ per $\mathrm{mm}^{2}$ ) (Tables $\left.2-3\right)$.
Oil cells are found on both surfaces in G. adhaerens (albus bract), G. bicolor, G. cambodgensis, G. globulifera, G. marantina, G. pendula, and G. siamensis, while in $G$. winitii they are found on the adaxial surface (Fig. 4i). For the abaxial surface oil cells are present in G. adhaerens (violaceus bract), G. albiflora var. aurea, G. annamensis, G. laeta, G. reflexa, and $G$. sherwoodiana. Rhombic crystals are present on both surfaces of all species observed except for G. adhaerens (albus bract), G. albiflora var. aurea, G. globulifera, G. nuda, G. pendula, G. winitii, 
Table 2 Comparison of characteristics of leaf surface on adaxial side in genus Globba*

\begin{tabular}{|c|c|c|c|c|c|c|c|c|c|c|c|c|c|}
\hline \multirow[t]{2}{*}{ Taxa } & \multirow[t]{2}{*}{$\mathrm{St}^{+}$} & \multirow{2}{*}{$\begin{array}{l}\text { WEP } \\
(\mu \mathrm{m})\end{array}$} & \multirow{2}{*}{$\begin{array}{l}\text { WSC } \\
(\mu \mathrm{m})\end{array}$} & \multirow{2}{*}{$\begin{array}{l}\text { ICR } \\
\text { rows }\end{array}$} & \multirow{2}{*}{$\begin{array}{l}\text { LGC } \\
(\mu \mathrm{m})\end{array}$} & \multirow{2}{*}{$\begin{array}{c}\mathrm{DSt} \\
\left(\mathrm{mm}^{-2}\right)\end{array}$} & \multicolumn{4}{|c|}{ Type of trichome } & \multirow{2}{*}{$\begin{array}{c}\mathrm{DT} \\
\left(\mathrm{mm}^{-2}\right)\end{array}$} & \multirow[t]{2}{*}{$\mathrm{Inc}^{+}$} & \multirow{2}{*}{$\begin{array}{l}\text { Col. } \\
\text { No. }\end{array}$} \\
\hline & & & & & & & $\mathrm{SU}(\mu \mathrm{m})$ & $\mathrm{LU}(\mu \mathrm{m})$ & $\mathrm{LB}(\mu \mathrm{m})$ & $\mathrm{G}(\mu \mathrm{m})$ & & & \\
\hline 1 & $\mathrm{~T}$ & $72.8 \pm 7.1$ & $20.0 \pm 2.9$ & 9 & $33.4 \pm 1.7$ & $14 \pm 3$ & $302 \pm 45$ & - & - & - & $28 \pm 2$ & - & К.41 \\
\hline 2 & $\mathrm{~T}$ & $63.0 \pm 7.6$ & $19.0 \pm 2.7$ & 6 & $30.8 \pm 1.4$ & $34 \pm 2$ & - & - & $463 \pm 39$ & - & $54 \pm 7$ & $\mathrm{O}$ & K.34 \\
\hline 3 & $\mathrm{~T}$ & $64 \pm 11$ & $15.0 \pm 2.9$ & 8 & $31.8 \pm 2.3$ & $5 \pm 3$ & - & $536 \pm 66$ & $454 \pm 18$ & - & $49 \pm 7$ & - & К.32 \\
\hline 4 & $\mathrm{~T}, \mathrm{P}$ & $65.8 \pm 3.1$ & $25.3 \pm 1.8$ & 19 & $36.5 \pm 1.5$ & $3 \pm 1$ & - & - & - & - & - & $\mathrm{R}$ & K. 40 \\
\hline 5 & $\mathrm{~T}$ & $74.3 \pm 10.5$ & $15.5 \pm 3.1$ & 6 & $39.4 \pm 3.2$ & $7 \pm 2$ & - & - & - & - & - & Sq & К. 60 \\
\hline 6 & T,P & $63.5 \pm 6.3$ & $16.0 \pm 2.1$ & 7 & $27.0 \pm 2.1$ & $10 \pm 3$ & $293 \pm 29$ & - & - & - & $13 \pm 3$ & $\mathrm{R}$ & К.46 \\
\hline 7 & T,P & $71.3 \pm 6.0$ & $23.5 \pm 4.7$ & 7 & $35.2 \pm 1.8$ & $29 \pm 4$ & - & - & - & $24 \pm 5$ & - & $\mathrm{O}, \mathrm{Sq}, \mathrm{R}, \mathrm{S}$ & K.42 \\
\hline 8 & T,P & $63.5 \pm 7.5$ & $21.5 \pm 3.8$ & 14 & $34.3 \pm 2.3$ & $22 \pm 3$ & - & - & - & $22 \pm 3$ & - & $\mathrm{R}, \mathrm{O}$ & K.55 \\
\hline 9 & $\mathrm{~T}$ & $70.5 \pm 3.7$ & $13.5 \pm 1.3$ & 10 & $29.5 \pm 2.2$ & $23 \pm 3$ & $245 \pm 46$ & - & - & - & $9 \pm 3$ & $\mathrm{R}, \mathrm{Rec}$ & К.50 \\
\hline 10 & $\mathrm{~T}$ & $73.3 \pm 5.8$ & $23.5 \pm 2.7$ & 7 & $32.5 \pm 2.4$ & $23 \pm 4$ & - & - & - & - & - & O & K.76 \\
\hline 11 & T,P & $70.3 \pm 8.2$ & $19.8 \pm 1.8$ & 9 & $39.6 \pm 1.7$ & $19 \pm 3$ & - & - & - & - & - & $\mathrm{R}, \mathrm{S}$ & К.37 \\
\hline 12 & $\mathrm{~T}, \mathrm{P}$ & $60.8 \pm 2.4$ & $15.5 \pm 2.0$ & 6 & $32.0 \pm 1.9$ & $67 \pm 4$ & $243 \pm 27$ & $456 \pm 47$ & - & - & $14 \pm 2$ & $O, R$ & K.44 \\
\hline 13 & T,P & $61.8 \pm 7.1$ & $17.0 \pm 2.0$ & 6 & $34.9 \pm 2.1$ & $8 \pm 2$ & - & - & - & - & - & $\mathrm{Sq}$ & К. 65 \\
\hline 14 & $\mathrm{~T}$ & $57.0 \pm 4.0$ & $13.3 \pm 2.4$ & 23 & $30.0 \pm 1.4$ & $12 \pm 2$ & - & - & - & - & - & - & K.47 \\
\hline 15 & $\mathrm{~T}$ & $66.3 \pm 4.4$ & $13.5 \pm 2.7$ & 22 & $30.5 \pm 1.5$ & $28 \pm 4$ & $80 \pm 11$ & - & - & - & $3 \pm 1$ & $\mathrm{O}, \mathrm{S}$ & К.68 \\
\hline 16 & $\mathrm{~T}, \mathrm{P}, \mathrm{H}$ & $64.8 \pm 6.8$ & $15.0 \pm 2.6$ & 26 & $29.5 \pm 2.0$ & $35 \pm 4$ & - & - & - & - & - & $\mathrm{R}$ & K. 80 \\
\hline 17 & $\mathrm{~T}, \mathrm{P}$ & $76.5 \pm 7.1$ & $26.5 \pm 3.8$ & 22 & $27.5 \pm 2.0$ & $21 \pm 2$ & - & - & - & - & - & $\mathrm{R}, \operatorname{Rec}$ & К.79 \\
\hline 18 & $\mathrm{~T}, \mathrm{P}, \mathrm{H}$ & $86.3 \pm 5.0$ & $16.5 \pm 4.3$ & 22 & $38.3 \pm 2.8$ & $7 \pm 2$ & - & - & - & - & - & $\mathrm{Sq}, \mathrm{R}$ & К.90 \\
\hline 19 & $\mathrm{~T}$ & $58.5 \pm 3.6$ & $17.0 \pm 2.0$ & 10 & $30.4 \pm 1.9$ & $2 \pm 1$ & - & - & - & - & - & $\mathrm{R}$ & К. 82 \\
\hline 20 & $\mathrm{~T}$ & $47.0 \pm 4.2$ & $17.0 \pm 3.5$ & 12 & $30.0 \pm 2.0$ & $5 \pm 3$ & $189 \pm 40$ & - & - & - & $7 \pm 4$ & - & K.36 \\
\hline 21 & T,P & $91.5 \pm 7.4$ & $21.3 \pm 3.8$ & 22 & $39.0 \pm 3.0$ & $13 \pm 2$ & $244 \pm 32$ & - & - & - & $8 \pm 3$ & Sq, R & К.72 \\
\hline 22 & T,P & $58.8 \pm 4.9$ & $16.3 \pm 3.2$ & 16 & $28.0 \pm 1.9$ & $20 \pm 4$ & - & - & - & - & - & $\mathrm{R}, \mathrm{S}$ & К. 85 \\
\hline 23 & T,P & $57.5 \pm 3.9$ & $15.5 \pm 3.1$ & 13 & $32.6 \pm 2.1$ & $41 \pm 3$ & - & $506 \pm 77$ & - & - & $50 \pm 3$ & $\mathrm{O}, \mathrm{Sq}, \mathrm{R}$ & К.39 \\
\hline 24 & T,P & $66.5 \pm 10.7$ & $19.8 \pm 5.1$ & 12 & $37.0 \pm 1.5$ & $21 \pm 2$ & - & - & - & - & - & $\mathrm{R}$ & К. 83 \\
\hline 25 & T,P & $74.5 \pm 5.0$ & $17.3 \pm 3.6$ & 22 & $30.6 \pm 2.3$ & $8 \pm 3$ & $316 \pm 33$ & - & - & - & $47 \pm 6$ & $\mathrm{O}, \mathrm{Sq}$ & К.35 \\
\hline 26 & $\mathrm{~T}$ & $68.3 \pm 3.7$ & $13.0 \pm 2.0$ & 7 & $35.3 \pm 2.1$ & $11 \pm 3$ & - & - & - & - & - & $S$ & К. 81 \\
\hline
\end{tabular}

"St $=$ stomata, WEP $=$ width of epidermal cell, WSC $=$ width of subsidiary cell, ICR $=$ intercostal regions, LGC $=$ length of guard cell, DSt = density of stomata, $\mathrm{SU}=$ short, simple unicellular, $\mathrm{LU}=$ long, simple unicellular, $\mathrm{LB}=$ long, biseriate, $\mathrm{G}=$ glandular, DT = density of trichome, Inc = inclusion, Col. No. = collected number, K. = Kajornjit.

$\dagger 1=G$. adhaerens Gagnep. (violaceus bract), $2=$ G. adhaerens Gagnep. (albus bract), $3=G$. aff. winitii, $4=$ G. albiflora var. albiflora, $5=$ G. albiflora var. aurea, $6=$ G. annamensis Gagnep., $7=$ G. bicolor Gagnep., $8=$ G. cambodgensis Gagnep., $9=$ G. candida Gagnep., $10=$ G. globulifera Gagnep., $11=$ G. laeta K.Larsen., $12=$ G. marantina, $13=$ G. nuda K.Larsen., $14=$ G. panicoides Miq., $15=$ G. pendula Roxb., $16=$ G. praecox K.J.Williams \& Paisooks., $17=$ G. purpurascens Craib, $18=$ G. racemosa Sm., $19=$ G. reflexa Craib, $20=$ G. schomburgkii Hook.f., $21=$ G. sessiliflora Sims, $22=$ G. sherwoodiana W.J.Kress \& V.Gowda, $23=$ G. siamensis (Hemsl.) Hemsl., $24=G$. williamsiana M.F.Newman, $25=G$. winitii C.H.Wright, $26=G$. xantholeuca Craib.

$* \mathrm{~T}=$ tetracytic, $\mathrm{P}=$ pentacytic, $\mathrm{H}=$ hexacytic, $\mathrm{O}=$ oil cell, $\mathrm{R}=$ rhombic crystal, $\mathrm{Rec}=$ rectangle crystal, $\mathrm{S}=$ silica bodies, $\mathrm{Sq}=$ square crystal.

and G. xantholeuca, where rhombic crystals are not found on both surfaces (Fig. 4j). Square and rectangle crystal are observed on both surfaces in G. bicolor, G. laeta, G. nuda, G. panicoides, G. racemosa, and G. purpurascens (Tables 2-3, Fig. 4k, 1). Silica sand (Fig. $4 \mathrm{~m}$ ) and hexagonal crystals are found only on the abaxial surface (Fig. 4n). Silica bodies occur on both surfaces above and below the veins, with one silica body per cell. Silica bodies are present on the adaxial surface in G. bicolor, G. laeta, G. pendula, G. sherwoodiana, and G. xantholeuca, while for the abaxial surface they are present in G. globulifera and G. panicoides (Fig. 4o). Our results reveal that they are not found on the adaxial surface in G. adhaerens (violaceus bract), G. aff. winitii, G. panicoides, and G. schomburgkii or on the abaxial surface in G. praecox.

\section{Transverse section of the lamina}

In the surface view, the epidermal cells on both surfaces are rectangle to polygonal, unequal in size; anticlinal walls of adaxial and abaxial cells are straight (Fig. 5), adaxial cells larger than abaxial cells. Thin cuticle and stomata are found on both surfaces of all species. Guard cells are located at the same level as the epidermis. Most of the studied species have more stomata on the abaxial surface than the adaxial surface, except in G. cambodgensis, G. candida, G. laeta, G. marantina, G. purpurascens, G. winitii, and G. xantholeuca, which have stomata on both surfaces (Table 4). Long, simple unicellular trichomes are present on the abaxial surface, which is found in 15 taxa, except in G. albiflora var. albiflora, G. albiflora var. aurea, G. cambodgensis, G. globulifera, G. panicoides, G. purpurascens, G. racemosa, G. reflexa, G. williamsiana, G. wini- 
Table 3 Comparison of characteristics of leaf surface on abaxial side in genus Globba*

\begin{tabular}{|c|c|c|c|c|c|c|c|c|c|c|c|c|}
\hline \multirow[t]{2}{*}{ Taxa } & \multirow[t]{2}{*}{ St } & \multirow{2}{*}{$\begin{array}{l}\text { WEP } \\
(\mu \mathrm{m})\end{array}$} & \multirow{2}{*}{$\begin{array}{l}\text { WSC } \\
(\mu \mathrm{m})\end{array}$} & \multirow{2}{*}{$\begin{array}{l}\text { ICR } \\
\text { rows }\end{array}$} & \multirow{2}{*}{$\begin{array}{l}\text { LGC } \\
(\mu \mathrm{m})\end{array}$} & \multirow{2}{*}{$\begin{array}{c}\text { DSt } \\
\left(\mathrm{mm}^{-2}\right)\end{array}$} & \multicolumn{4}{|c|}{ Type of trichome } & \multirow{2}{*}{$\begin{array}{c}\mathrm{DT} \\
\left(\mathrm{mm}^{-2}\right)\end{array}$} & \multirow[t]{2}{*}{ Inclusion $^{+}$} \\
\hline & & & & & & & $\mathrm{SU}(\mu \mathrm{m})$ & $\mathrm{LU}(\mu \mathrm{m})$ & $\mathrm{LB}(\mu \mathrm{m})$ & $\mathrm{G}(\mu \mathrm{m})$ & & \\
\hline 1 & $\mathrm{~T}$ & $39.0 \pm 3.8$ & $12.3 \pm 1.8$ & 11 & $33.8 \pm 1.3$ & $204 \pm 6$ & $369 \pm 34$ & - & - & - & $99 \pm 5$ & $\mathrm{He}, \mathrm{O}, \mathrm{R}, \mathrm{Ss}$ \\
\hline 2 & $\mathrm{~T}, \mathrm{P}$ & $38.3 \pm 6.0$ & $15.1 \pm 2.0$ & 9 & $33.6 \pm 2.2$ & $213 \pm 4$ & - & - & $568 \pm 44$ & - & $135 \pm 3$ & $\mathrm{He}, \mathrm{O}, \mathrm{R}, \mathrm{Ss}$ \\
\hline 3 & $\mathrm{~T}$ & $35.8 \pm 4.1$ & $10.5 \pm 2.0$ & 12 & $31.5 \pm 1.9$ & $202 \pm 1$ & - & $612 \pm 70$ & $592 \pm 42$ & - & $126 \pm 9$ & R,Ss \\
\hline 4 & T,P & $59.5 \pm 6.1$ & $21.3 \pm 2.4$ & 10 & $36.0 \pm 1.9$ & $93 \pm 6$ & - & - & - & - & - & $\mathrm{He}, \mathrm{Sq}, \mathrm{R}, \mathrm{Rec}$ \\
\hline 5 & $\mathrm{~T}, \mathrm{P}$ & $35.8 \pm 4.4$ & $9.3 \pm 3.1$ & 5 & $38.5 \pm 1.9$ & $240 \pm 1$ & - & - & - & - & - & $\mathrm{O}, \mathrm{R}$ \\
\hline 6 & $\mathrm{~T}$ & $44.0 \pm 6.6$ & $16.0 \pm 1.3$ & 12 & $27.8 \pm 2.1$ & $182 \pm 2$ & - & $516 \pm 73$ & - & - & $176 \pm 3$ & $\mathrm{O}, \mathrm{Sq}, \mathrm{R}$ \\
\hline 7 & $\mathrm{~T}$ & $60.5 \pm 7.8$ & $22.8 \pm 3.4$ & 11 & $34.5 \pm 2.5$ & $184 \pm 12$ & $76 \pm 14$ & - & - & - & $8 \pm 1$ & $\mathrm{O}, \mathrm{Sq}, \mathrm{R}, \mathrm{Rec}$ \\
\hline 8 & $\mathrm{~T}$ & $52 \pm 10$ & $15.8 \pm 2.9$ & 6 & $34.8 \pm 1.8$ & $219 \pm 6$ & $57 \pm 8$ & - & & $20 \pm 5$ & $24 \pm 3$ & Sq,R,Ss \\
\hline 9 & $\mathrm{~T}$ & $56 \pm 11$ & $14.5 \pm 2.0$ & 8 & $28.5 \pm 2.4$ & $221 \pm 7$ & $170 \pm 24$ & - & - & $18 \pm 4$ & $219 \pm 6$ & $\mathrm{Sq}, \mathrm{R}$ \\
\hline 10 & $\mathrm{~T}$ & $50.5 \pm 3.7$ & $17.5 \pm 3.7$ & 13 & $35.4 \pm 1.9$ & $183 \pm 8$ & - & - & - & - & - & $\mathrm{O}, \mathrm{Sq}, \mathrm{R}, \mathrm{S}$ \\
\hline 11 & $\mathrm{~T}$ & $45.3 \pm 3.6$ & $15.5 \pm 3.1$ & 8 & $36.1 \pm 1.9$ & $169 \pm 5$ & $298 \pm 35$ & - & - & - & $157 \pm 4$ & O,R,Sq,Ss \\
\hline 12 & $\mathrm{~T}$ & $44.5 \pm 3.5$ & $15.5 \pm 2.0$ & 7 & $32.1 \pm 1.9$ & $220 \pm 3$ & - & - & - & - & - & $\mathrm{He}, \mathrm{O}, \mathrm{R}, \mathrm{Sq}, \mathrm{Ss}$ \\
\hline 13 & $\mathrm{~T}$ & $33.5 \pm 2.1$ & $8.0 \pm 2.0$ & 6 & $34.8 \pm 2.1$ & $215 \pm 12$ & - & - & - & - & - & $\mathrm{He}, \mathrm{Sq}, \mathrm{R}, \mathrm{Rec}$ \\
\hline 14 & $\mathrm{~T}$ & $55.8 \pm 4.4$ & $13.0 \pm 2.0$ & 5 & $32.5 \pm 2.4$ & $89 \pm 4$ & $100 \pm 10$ & - & - & - & $40 \pm 8$ & R,Rec,S \\
\hline 15 & $\mathrm{~T}, \mathrm{P}$ & $45.3 \pm 3.4$ & $11.5 \pm 2.7$ & 9 & $34.3 \pm 1.8$ & $149 \pm 4$ & $70 \pm 8$ & - & - & - & $80 \pm 5$ & $\mathrm{O}, \mathrm{R}$ \\
\hline 16 & $\mathrm{~T}, \mathrm{P}$ & $36.0 \pm 3.9$ & $13.5 \pm 2.7$ & 8 & $25.5 \pm 2.0$ & $89 \pm 4$ & $91 \pm 17$ & - & - & $23 \pm 5$ & $103 \pm 7$ & - \\
\hline 17 & $\mathrm{~T}$ & $40.3 \pm 2.8$ & $18.0 \pm 2.0$ & 14 & $27.5 \pm 2.8$ & $178 \pm 4$ & - & - & - & $22 \pm 4$ & - & $\mathrm{O}, \mathrm{R}, \mathrm{Rec}$ \\
\hline 18 & $\mathrm{~T}$ & $55.0 \pm 5.1$ & $12.5 \pm 2.9$ & 15 & $49.5 \pm 4.1$ & $88 \pm 8$ & $114 \pm 12$ & - & - & $20 \pm 2$ & $94 \pm 7$ & $\mathrm{Sq}, \mathrm{R}$ \\
\hline 19 & $\mathrm{~T}$ & $38.5 \pm 3.6$ & $13.3 \pm 1.2$ & 13 & $35.5 \pm 1.9$ & $273 \pm 2$ & - & - & - & $17 \pm 5$ & - & $\mathrm{O}, \mathrm{Sq}, \mathrm{R}$ \\
\hline 20 & $\mathrm{~T}$ & $44.0 \pm 2.7$ & $10.5 \pm 2.0$ & 6 & $31.8 \pm 1.8$ & $218 \pm 13$ & $360 \pm 31$ & - & - & - & $217 \pm 5$ & $\mathrm{R}$ \\
\hline 21 & $\mathrm{~T}$ & $45.0 \pm 3.7$ & $12.5 \pm 1.7$ & 9 & $49.5 \pm 2.5$ & $124 \pm 4$ & $164 \pm 14$ & - & & - & $98 \pm 4$ & $\mathrm{R}, \mathrm{Ss}$ \\
\hline 22 & $\mathrm{~T}$ & $46.3 \pm 3.8$ & $17.0 \pm 2.6$ & 12 & $28.8 \pm 1.3$ & $215 \pm 1$ & - & - & - & $22 \pm 4$ & - & $\mathrm{He}, \mathrm{O}, \mathrm{R}, \mathrm{Sq}, \mathrm{Rec}$ \\
\hline 23 & $\mathrm{~T}$ & $37.0 \pm 4.5$ & $13.0 \pm 2.0$ & 10 & $34.9 \pm 1.5$ & $224 \pm 4$ & - & $542 \pm 75$ & $468 \pm 43$ & - & $150 \pm 3$ & $\mathrm{O}, \mathrm{R}$ \\
\hline 24 & $\mathrm{~T}$ & $65.5 \pm 8.9$ & $19.3 \pm 4.1$ & 14 & $38.3 \pm 3.0$ & $93 \pm 5$ & - & - & - & $21 \pm 6$ & - & $\mathrm{He}, \mathrm{Sq}, \mathrm{R}$ \\
\hline 25 & $\mathrm{~T}$ & $51.8 \pm 5.5$ & $14.5 \pm 2.0$ & 18 & $31.4 \pm 2.1$ & $150 \pm 3$ & - & $521 \pm 64$ & $604 \pm 38$ & $20 \pm 7$ & $125 \pm 3$ & R \\
\hline 26 & $\mathrm{~T}$ & $38.5 \pm 2.4$ & $10.0 \pm 2.4$ & 9 & $31.0 \pm 1.7$ & $216 \pm 8$ & - & - & - & $24 \pm 5$ & - & $\mathrm{R}$ \\
\hline
\end{tabular}

" Using the same notation as in Table 2.

${ }^{*} \mathrm{He}=$ hexagonal crystal, Ss $=$ silica sand.

tii, and G. xantholeuca, which are not found to have long, simple unicellular trichomes. In $G$. adhaerens (albus bract), G. aff. winitii, G. pendula, and G. siamensis long, simple unicellular trichomes are present on both surfaces.

Most of the studied species have a hypodermis on the abaxial surface with only one row (Fig. 5a), square or pentagonal shape, the hypodermis is larger than the epidermal cells. Rhombic crystals (Fig. 5a) are present in the hypodermis of 13 taxa, except G. adhaerens (violaceus bract), G. adhaerens (albus bract), G. albiflora var. albiflora, G. albiflora var. aurea, G. annamensis, G. candida, G. panicoides, G. praecox, G. reflexa, G. schomburgkii, G. sessiliflo$r a$, G. siamensis, and G. winitii, in which rhombic crystals are absent in the hypodermis. Hexagonal crystals (Fig. 5c) are found on the hypodermis in G. aff. winitii, G. bicolor, G. cambodgensis, G. laeta, G. marantina, G. purpurascens, G. sherwoodiana, G. williamsiana, and G. xantholeuca.

The Chlorenchyma tissue occupies the middle region of the leaf blade. The palisade and spongy mesophyll range from one to three layers. The palisade cells are ellipse shaped in periclinal rows, with about one to three cells located under the epidermal cell. The spongy cells next to the palisade cells are hemispherical or hemiellipsoidal on the abaxial side. The width of the mesophyll varies from $51.5 \pm 3.8 \mu \mathrm{m}$ in $G$. praecox to $116.0 \pm 9.0 \mu \mathrm{m}$ in $G$. adhaerens (albus bract). Inclusion, rhombic, square, hexagonal crystals, and silica sand are present in the mesophyll, with most of the studied species having rhombic crystals in the mesophyll. Vascular bundles are collateral with tracheary elements consisting of one to two metaxylem and few protoxylem cells flanked by colourless parenchyma laterally. The bundle sheath extends to both sides of the epidermal cells in all species.

\section{Midrib}

The shape of all Thai Globba in the transverse section curves to a U-shape on both sides (Fig. 5eh), except in G. globulifera which is slightly flat (Fig. 5d). The epidermal cells on both surfaces are four to seven sided. Most of the species assessed show long, simple unicellular trichomes on the abaxial surface, except in G. candida and G. siamensis, which has long, simple unicellular trichomes on both surfaces. The vascular system is arranged in several arcs; description follows Tomlinson ${ }^{22}$ where the main arc is described as arc I, abaxial arc as arc II, adaxial arc as arc III, and a fourth arc closer to the adaxial surface as arc IV. Four groups in the species are recognized: Arc I (Fig. 5e) found in G. nuda, 
Table 4 Comparison of characteristics of transverse sections of leaf blades in genus Globba*

\begin{tabular}{|c|c|c|c|c|c|c|c|c|c|c|c|c|c|}
\hline \multirow[t]{2}{*}{ Taxa } & \multirow[t]{2}{*}{ LU } & \multirow[t]{2}{*}{ Stomata } & \multicolumn{2}{|c|}{ Epidermis width } & \multicolumn{4}{|c|}{ Hypodermis } & \multicolumn{5}{|c|}{ Mesophyll } \\
\hline & & & $\mathrm{AD}(\mu \mathrm{m})$ & $\mathrm{AB}(\mu \mathrm{m})$ & $\mathrm{AD}$ & $\mathrm{AB}$ & $\mathrm{R}$ & $\mathrm{He}$ & Width $(\mu \mathrm{m})$ & PS & SG & Inc & Crystal \\
\hline 1 & $\mathrm{AD}, \mathrm{AB}$ & $\mathrm{AB}$ & $55.3 \pm 7.5$ & $34.3 \pm 4.4$ & - & - & - & - & $99.5 \pm 9.9$ & 1 & 2 & - & $\mathrm{R}, \mathrm{He}$ \\
\hline 2 & $\mathrm{AB}$ & $\mathrm{AB}$ & $61.5 \pm 7.8$ & $40.0 \pm 5.7$ & - & 1 & - & - & $116.0 \pm 9.0$ & 3 & 2 & - & - \\
\hline 3 & $\mathrm{AD}, \mathrm{AB}$ & $\mathrm{AB}$ & $56.0 \pm 6.0$ & $36.5 \pm 4.6$ & - & 1 & / & / & $100.3 \pm 7.1$ & 2 & 2 & / & $\mathrm{R}, \mathrm{Ss}, \mathrm{He}$ \\
\hline 4 & - & $\mathrm{AB}$ & $50.8 \pm 6.6$ & $51.3 \pm 5.3$ & - & - & - & - & $52.3 \pm 4.9$ & 1 & 2 & / & $\mathrm{R}$ \\
\hline 5 & - & $\mathrm{AB}$ & $63.5 \pm 11.9$ & $36.8 \pm 3.3$ & - & - & - & - & $70.3 \pm 5.5$ & 2 & 1 & - & $\mathrm{Sq}$ \\
\hline 6 & $\mathrm{AB}$ & $\mathrm{AB}$ & $52.3 \pm 9.1$ & $38.5 \pm 3.6$ & - & - & - & - & $57.0 \pm 5.0$ & 2 & 2 & / & $\mathrm{R}, \mathrm{Ss}$ \\
\hline 7 & $\mathrm{AB}$ & $\mathrm{AB}$ & $53.3 \pm 6.0$ & $43.3 \pm 5.1$ & - & 1 & 1 & 1 & $77.3 \pm 7.9$ & 1 & 2 & - & - \\
\hline 8 & - & $\mathrm{AD}, \mathrm{AB}$ & $65.0 \pm 7.1$ & $50.3 \pm 7.9$ & - & 1 & / & i & $63.0 \pm 5.2$ & 1 & 2 & - & - \\
\hline 9 & $\mathrm{AB}$ & $\mathrm{AD}, \mathrm{AB}$ & $59.3 \pm 7.1$ & $53.5 \pm 7.1$ & - & - & - & - & $65.5 \pm 6.9$ & 1 & 3 & - & $\mathrm{Sq}, \mathrm{He}$ \\
\hline 10 & - & $\mathrm{AB}$ & $52.0 \pm 11.4$ & $40.3 \pm 5.6$ & - & 1 & / & - & $89.3 \pm 7.8$ & 2 & 2 & - & Ss,Sq,He \\
\hline 11 & $\mathrm{AB}$ & $\mathrm{AD}, \mathrm{AB}$ & $62.3 \pm 7.5$ & $51.5 \pm 7.5$ & - & 1 & / & I & $82.3 \pm 5.1$ & 2 & 2 & I & - \\
\hline 12 & $\mathrm{AB}$ & $\mathrm{AD}, \mathrm{AB}$ & $73.3 \pm 10.7$ & $52.5 \pm 7.0$ & - & 1 & / & I & $60.8 \pm 3.3$ & 2 & 2 & / & $\mathrm{R}, \mathrm{Ss}, \mathrm{Sq}, \mathrm{He}$ \\
\hline 13 & $\mathrm{AB}$ & $\mathrm{AB}$ & $34.5 \pm 4.2$ & $19.5 \pm 3.3$ & - & 1 & / & - & $58.3 \pm 4.6$ & 1 & 2 & - & $\mathrm{R}, \mathrm{Ss}, \mathrm{Sq}$ \\
\hline 14 & - & $\mathrm{AB}$ & $52.5 \pm 5.2$ & $41.0 \pm 7.5$ & - & - & - & - & $40.0 \pm 4.9$ & 1 & 1 & - & $\mathrm{R}$ \\
\hline 15 & $\mathrm{AD}, \mathrm{AB}$ & $\mathrm{AB}$ & $53.5 \pm 9.2$ & $45.8 \pm 5.5$ & - & 1 & / & - & $65.8 \pm 6.4$ & 2 & 1 & / & - \\
\hline 16 & $\mathrm{AB}$ & $\mathrm{AB}$ & $44.5 \pm 11.5$ & $34.0 \pm 5.3$ & - & 1 & - & - & $51.5 \pm 3.8$ & 2 & 1 & - & $\mathrm{R}$ \\
\hline 17 & - & $\mathrm{AD}, \mathrm{AB}$ & $61.3 \pm 7.7$ & $53.8 \pm 6.9$ & - & 1 & / & I & $99.3 \pm 5.0$ & 2 & 3 & - & - \\
\hline 18 & - & $\mathrm{AB}$ & $61.3 \pm 5.0$ & $49.8 \pm 10.6$ & - & 1 & / & - & $72.8 \pm 2.8$ & 2 & 2 & - & $\mathrm{R}, \mathrm{He}$ \\
\hline 19 & - & $\mathrm{AB}$ & $54.8 \pm 6.1$ & $41.5 \pm 6.0$ & - & - & - & - & $87.3 \pm 11.5$ & 2 & 3 & 1 & $\mathrm{R}, \mathrm{Sq}, \mathrm{He}$ \\
\hline 20 & $\mathrm{AB}$ & $\mathrm{AB}$ & $53.0 \pm 8.2$ & $42.8 \pm 6.6$ & - & 1 & - & - & $74.5 \pm 7.4$ & 1 & 3 & - & $\mathrm{R}, \mathrm{Sq}, \mathrm{He}$ \\
\hline 21 & $\mathrm{AB}$ & $\mathrm{AB}$ & $57.5 \pm 5.3$ & $47.5 \pm 5.8$ & - & - & - & - & $92.8 \pm 8.4$ & 2 & 3 & I & - \\
\hline 22 & $\mathrm{AB}$ & $\mathrm{AB}$ & $59.8 \pm 8.5$ & $49.5 \pm 8.8$ & - & 1 & I & 1 & $52.5 \pm 6.9$ & 1 & 2 & - & $\mathrm{Ss}, \mathrm{Sq}, \mathrm{He}$ \\
\hline 23 & $\mathrm{AD}, \mathrm{AB}$ & $\mathrm{AB}$ & $54.0 \pm 7.1$ & $39.0 \pm 4.1$ & - & 1 & - & - & $79.0 \pm 5.4$ & 1 & 2 & - & R,Sq \\
\hline 24 & - & $\mathrm{AB}$ & $61.3 \pm 9.0$ & $58.3 \pm 7.0$ & - & 1 & 1 & 1 & $74.5 \pm 8.1$ & 2 & 1 & - & Ss \\
\hline 25 & - & $\mathrm{AD}, \mathrm{AB}$ & $58.8 \pm 5.0$ & $65.0 \pm 7.3$ & - & - & - & - & $60.3 \pm 7.4$ & 2 & 2 & / & $\mathrm{R}$ \\
\hline 26 & - & $\mathrm{AD}, \mathrm{AB}$ & $69.5 \pm 14.3$ & $54.3 \pm 12.1$ & - & 1 & / & / & $81.3 \pm 9.6$ & 2 & 2 & - & Ss, He \\
\hline
\end{tabular}

" Using the same notation as in Tables 2 and $3, \mathrm{AB}=$ abaxial side, $\mathrm{AD}=$ adaxial side, $\mathrm{PS}=$ number of palisade layers, $\mathrm{SG}=$ number of spongy layers, / = present.

G. pendula, and G. winitii; arcs I and II (Fig. 5f) presented in G. adhaerens (violaceus bract), G. adhaerens (albus bract), G. albiflora var. aurea, G. annamensis, G. bicolor, G. panicoides, G. praecox, and G. siamensis; arcs I, II, and III (Fig. $5 \mathrm{~g}$ ) presented in G. aff. winitii, G. laeta, G. marantina, G. racemosa, G. sessiliflora, and G. sherwoodiana; arcs I, II, and IV (Fig. 5h) found in G. albiflora var. albiflora, G. cambodgensis, G. candida, G. globulifera, G. purpurascens, G. reflexa, G. williamsiana, and G. xantholeuca; and arcs I, II, III, and IV found only in G. schomburgkii. Tannin is present only in G. laeta. Rhombic, rectangle, square, hexagonal crystals, and silica sand are present in the midrib of all species of the genus Globba. Most of the studied species have silica sand and rhombic crystals. In G. albiflora var. albiflora, G. panicoides, and G. sessiliflora there are no crystals in the midrib.

\section{Leaf margin}

Three types of leaf margin can be recognized, based on the shape of the margin in transverse section, including taper (Fig. 5i), curved up (Fig. 5j), and curved down (Fig. 5k). The length of the leaf margin (measured from the last group of the vascular bundle to the apex leaf margins) varies from
$82.0 \pm 7.9 \mu \mathrm{m}$ in $G$. nuda to $403.0 \pm 8.2 \mu \mathrm{m}$ in G. williamsiana.

\section{DISCUSSION}

The generalized pollen morphology of all the species in the genus Globba are monad, radial symmetry, apolar, and inaperturate, which is similar to that of most genera in Zingiberaceae ${ }^{9-15,20}$. The medium sized pollen grains are the most dominant and are found in 18 taxa of Globba in this study. Two pollen sizes, medium and large, are observed in this genus. The latter type has never been recorded for the genus Globba in previous work by Mangaly and Nayar ${ }^{19}$, which reported that the pollen size of G. ophioglossa was the medium size. Hence the large pollen size is reported here for the first time in the genus. Three main types of pollen shape are recognized, oblate-spheroidal, spheroidal, and prolatespheroidal. Most species have the spheroidal shape for their pollen. The obtained data in the present study are in agreement with Liang ${ }^{17}$, Mangaly and Nayar $^{19}$, Syamsuardi ${ }^{21}$, Jones and Pearce ${ }^{22}$, who all reported that the shapes of the pollen grains in the genus Globba are spherical and prolate, but in this study we also found oblate-spheroidal and prolate-spheroidal shaped pollen for the Globba. 
Table 5 Comparison of characteristics of transverse sections of midribs and leaf margins in genus Globba.

\begin{tabular}{|c|c|c|c|c|c|c|c|c|}
\hline \multirow[t]{2}{*}{ Taxa } & \multicolumn{6}{|c|}{ Midrib } & \multicolumn{2}{|c|}{ Leaf margins } \\
\hline & Shape AD & Shape AB & LU & Vascular system & Inc & Crystal & Shape & Length $(\mu \mathrm{m})$ \\
\hline 1 & $\mathrm{U}$ & $\mathrm{U}$ & $\mathrm{AB}$ & Arc I, Arc II & - & $\mathrm{R}, \mathrm{Rec}$ & taper & $135 \pm 10$ \\
\hline 2 & $\mathrm{U}$ & $\mathrm{U}$ & $\mathrm{AB}$ & Arc I, Arc II & - & $\operatorname{Rec}$ & curved up & $259 \pm 47$ \\
\hline 3 & $\mathrm{U}$ & $\mathrm{U}$ & $\mathrm{AB}$ & Arc I, Arc II, Arc III & - & Rec, Ss & curved up & $163 \pm 17$ \\
\hline 4 & $\mathrm{U}$ & $\mathrm{U}$ & - & Arc I, Arc II, Arc IV & - & - & taper & $260 \pm 38$ \\
\hline 5 & $\mathrm{U}$ & $\mathrm{U}$ & - & Arc I, Arc II & - & $\mathrm{R}, \mathrm{Rec}$ & curved down & $193 \pm 18$ \\
\hline 6 & $\mathrm{U}$ & $\mathrm{U}$ & $\mathrm{AB}$ & Arc I, Arc II & - & $\mathrm{R}, \mathrm{Ss}$ & curved up & $165 \pm 11$ \\
\hline 7 & $\mathrm{U}$ & $\mathrm{U}$ & - & Arc I, Arc II & - & Ss & taper & $226 \pm 12$ \\
\hline 8 & $\mathrm{U}$ & $\mathrm{U}$ & - & Arc I, Arc II, Arc IV & - & $\mathrm{R}$ & curved down & $203 \pm 12$ \\
\hline 9 & $\mathrm{U}$ & $\mathrm{U}$ & $\mathrm{AD}, \mathrm{AB}$ & Arc I, Arc II, Arc IV & - & $\mathrm{R}, \mathrm{Sq}$ & curved down & $195 \pm 9$ \\
\hline 10 & slightly flat & $\mathrm{U}$ & - & Arc I, Arc II, Arc IV & - & Ss & taper & $291 \pm 17$ \\
\hline 11 & $\mathrm{U}$ & $\mathrm{U}$ & $\mathrm{AB}$ & Arc I, Arc II, Arc III & $\mathrm{T}$ & $\mathrm{R}, \mathrm{Ss}$ & taper & $281 \pm 26$ \\
\hline 12 & $\mathrm{U}$ & $\mathrm{U}$ & - & Arc I, Arc II, Arc III & - & Ss & taper & $262 \pm 8$ \\
\hline 13 & $\mathrm{U}$ & $\mathrm{U}$ & $A B$ & Arc I & - & Ss & taper & $82 \pm 8$ \\
\hline 14 & $\mathrm{U}$ & $\mathrm{U}$ & $\mathrm{AB}$ & Arc I, Arc II & - & - & curved down & $324 \pm 48$ \\
\hline 15 & $\mathrm{U}$ & $\mathrm{U}$ & - & Arc I & - & $\mathrm{R}$ & taper & $280 \pm 7$ \\
\hline 16 & $\mathrm{U}$ & $\mathrm{U}$ & - & Arc I, Arc II & - & $\mathrm{He}$ & taper & $203 \pm 7$ \\
\hline 17 & $\mathrm{U}$ & $\mathrm{U}$ & - & Arc I, Arc II, Arc IV & - & $\mathrm{R}, \mathrm{Rec}$ & taper & $344 \pm 14$ \\
\hline 18 & $\mathrm{U}$ & $\mathrm{U}$ & $\mathrm{AB}$ & Arc I, Arc II, Arc III & - & Rec & taper & $265 \pm 11$ \\
\hline 19 & $\mathrm{U}$ & $\mathrm{U}$ & - & Arc I, Arc II, Arc IV & - & Ss & curved down & $237 \pm 12$ \\
\hline 20 & $\mathrm{U}$ & $\mathrm{U}$ & $\mathrm{AB}$ & Arc I, Arc II, Arc III, Arc IV & - & $\mathrm{R}$ & curved up & $188 \pm 10$ \\
\hline 21 & $\mathrm{U}$ & $\mathrm{U}$ & $\mathrm{AB}$ & Arc I, Arc II, Arc III & - & - & curved down & $378 \pm 11$ \\
\hline 22 & $\mathrm{U}$ & $\mathrm{U}$ & $\mathrm{AB}$ & Arc I, Arc II, Arc III & - & Ss & curved down & $323 \pm 24$ \\
\hline 23 & $\mathrm{U}$ & $\mathrm{U}$ & $\mathrm{AD}, \mathrm{AB}$ & Arc I, Arc II & - & Rec & taper & $129 \pm 7$ \\
\hline 24 & $\mathrm{U}$ & $\mathrm{U}$ & - & Arc I, Arc II, Arc IV & - & $\mathrm{R}$, Ss & curved down & $403 \pm 8$ \\
\hline 25 & $\mathrm{U}$ & $\mathrm{U}$ & - & Arc I & - & $\mathrm{R}$, Ss & taper & $360 \pm 8$ \\
\hline 26 & $\mathrm{U}$ & $\mathrm{U}$ & - & Arc I, Arc II, Arc IV & - & Ss & curved down & $298 \pm 9$ \\
\hline
\end{tabular}

" Using the same notation as in Table 4, Arc I, Arc II, Arc III, Arc IV = vascular systems, T = tannin, U = U-shape.

The $\mathrm{P} / \mathrm{E}$ ratio shows extensive differences in the shape class of the pollen grains among the studied taxa. The three main types of pollen grain are exine sculpturing as detected, viz., short-echinate with psilate between the spine, short-echinate with rugulate between the spine and psilate. These results agree with Chen ${ }^{18}$, Liang ${ }^{17}$, Mangaly and Nayar ${ }^{19}$, and Syamsuardi ${ }^{21}$, who reported that the exine sculpturing of pollen grains of the genus Globba are short-echinate and echinate-psilate. However, Jones and Pearce ${ }^{22}$ found that the exine sculpturing of the pollen grains of $G$. propinqua is granulate with gemmae. In this study, we found the psilate type of exine ornamentation in the genus Globba for the first time. Most Thai Globba pollen is primitive because it is short-echinate pollen, except for G. panicoides which is advanced because the exine sculpturing is psilate. Our study confirms the pollen of the genus Globba are inaperturate, which corresponds to Liang ${ }^{17}$, Chen ${ }^{18}$, Mangaly and Nayar ${ }^{19}$, Syamsuardi $^{21}$, Jones and Pearce ${ }^{22}$ who reported that the aperture of Globba is inaperturate. The spine apex can be divided into two groups, namely, sharp or blunt, and according to Kaewsri and Paisooksantivatana $^{20}$ the spine apexes of the genus Amomum have sharp or blunt apexes. In addition, the present study reports additional data, i.e., length of spine, width of spine, density of spine, distance between the spines, and wall thickness, which has never been reported in previous studies of the genus Globba. Furthermore, using these characters in combination with other characters, such as the internal structure of the pollen grains by transmission electron microscopy and molecular data, may help in clarifying the relationship between the closely related taxa and may help to further explain the taxonomic relationship within the genus.

In the second part of this study, detailed leaf anatomical features of Thai Globba were examined. The generalized anatomical characteristics of all species of Globba are as follows: epidermal cells on both surfaces are four to seven-sided, stomata on both surfaces are tetracytic, stomata develop on both surfaces but are more frequent on abaxial surface, subsidiary cells are rounded dome-shaped on both surfaces, epidermal cells on both surfaces in transverse section of lamina are rectangle to polygonal and anticlinal walls of adaxial and abaxial cells are straight, thin cuticle, palisade and spongy cells composed of 1-3 layers, vascular bundles are collateral consisting of 1-2 metaxylem and a few protoxylem and bundle sheath extension is found in both surfaces. Nevertheless, there are some characters that may be useful for species identification. Tomlinson ${ }^{23,24}$ and Lakoet ${ }^{26}$ reported the anatomical characters of some species belonging 

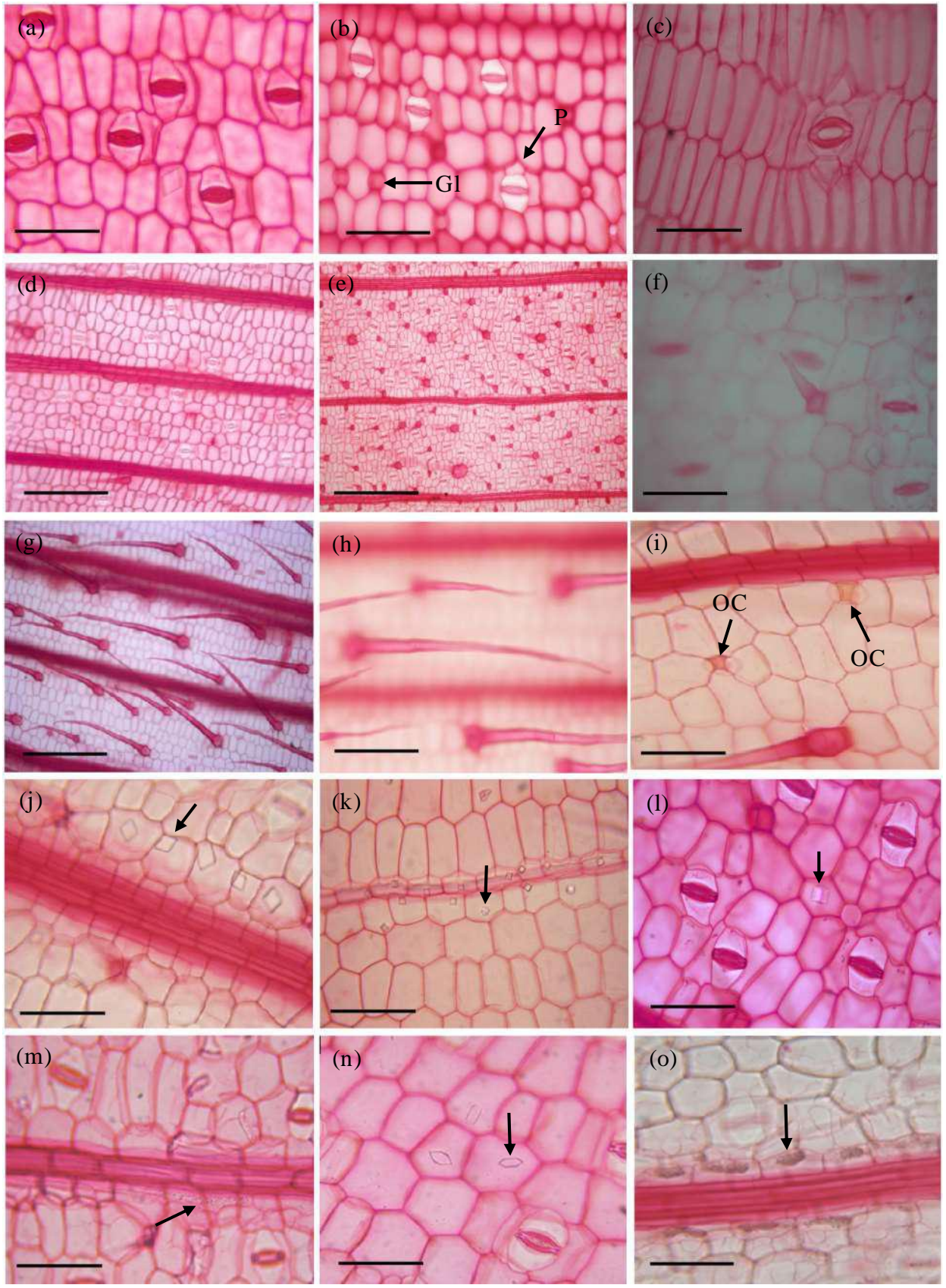

Fig. 4 Leaf epidermal anatomy of the genus Globba. (a) Tetracytic stomata on abaxial surface of G. marantina. (b) Pentacytic stomata and glandular trichome on abaxial surface of G. praecox (arrow). (c) Hexacytic stomata on adaxial surface of $G$. racemosa. (d) Number of rows in intercostal regions on adaxial surface of G. marantina as 6 rows. (e) Number of rows in intercostal regions on abaxial surface of $G$. annamensis as 12 rows. (f) Short, simple unicellular trichomes on abaxial surface of G. bicolor. (g) Long, simple unicellular trichomes on adaxial surface of $G$. aff. winitii. (h) Long, biseriate trichomes on adaxial surface of $G$. adhaerens (albus bract). (i) Oil cell on adaxial surface of G. adhaerens (albus bract) (arrow). (j) Rhombic crystal on abaxial surface of G. marantina (arrow). (k) Square crystal on adaxial surface of G. nuda (arrow). (1) Rectangle crystal on abaxial surface of G. panicoides (arrow). (m) Silica sand on abaxial surface of G. cambodgensis (arrow). (n) Hexagonal crystal on abaxial surface of G. albiflora var. albiflora (arrow). (o) Silica bodies on abaxial surface of G. globulifera (arrow). (a, b, c, f-o) scale bars $=50 \mu \mathrm{m}$; (d) scale bar $=100 \mu \mathrm{m}$; and (e) scale bar $=200 \mu \mathrm{m}$. Gl = Glandular trichome, $\mathrm{OC}=$ Oil cell, $\mathrm{P}=$ Pentacytic stomata. 


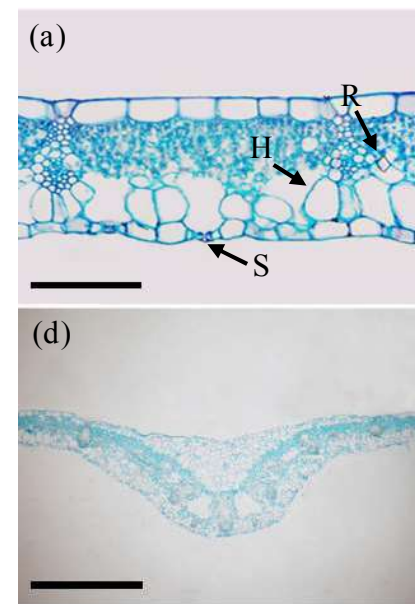

(g)

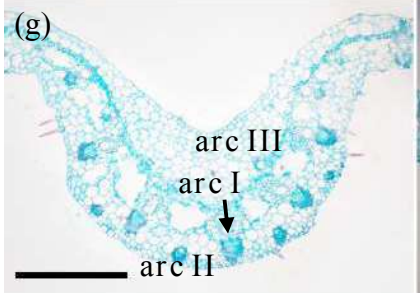

(j) (b)
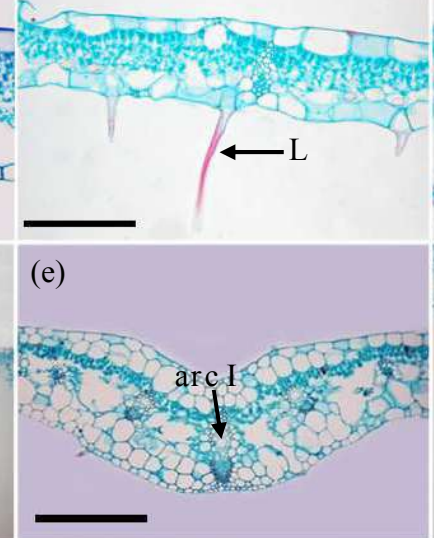

(h)
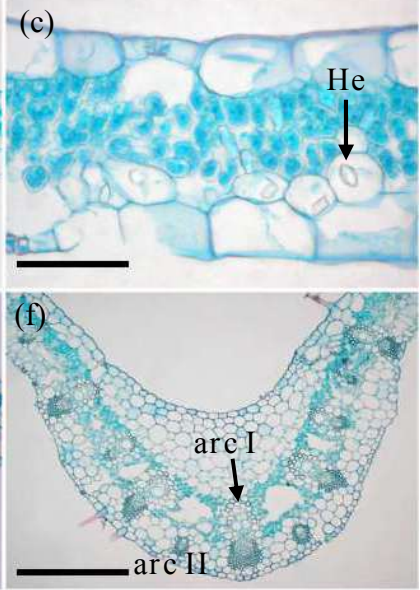

(i)

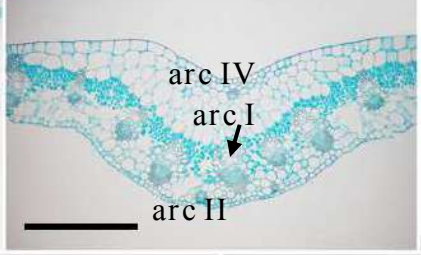

(k)

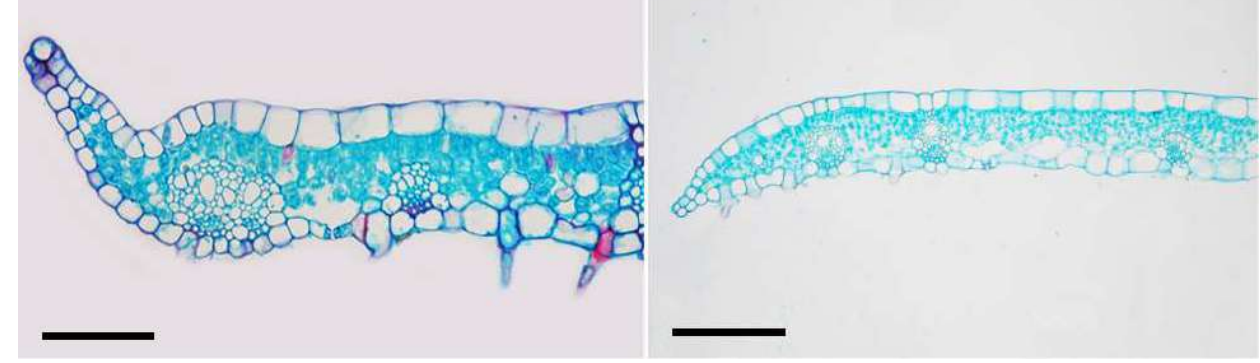

Fig. 5 Transverse sections of (a-c) leaf blades, (d-h) midribs, and (i-k) leaf margins. (a) Stomata, hypodermis, and rhombic crystal in G. schomburgkii (arrow). (b) Long, simple unicellular trichomes in G. candida (arrow). (c) Hexagonal crystal in G. xantholeuca (arrow). (d) Shape of midrib on the adaxial surface is slightly flat in G. globulifera. (e) Vascular system arc I in G. pendula (arrow). (f) Vascular system arcs I and II in G. adhaerens (albus bract) (arrow). (g) Vascular system arcs I, II, and III in G. racemosa. (h) Vascular system arcs I, II, and IV in G. reflexa. (i) Leaf margins taper in G. marantina. (j) Leaf margins curved up in G. annamensis. (k) Leaf margins curved down in G. candida. (a, e-g, h-k) scale bars $=200 \mu \mathrm{m}$; (b) and (d) scale bars $=250 \mu \mathrm{m}$; and (c) scale bar $=100 \mu \mathrm{m}$. H = Hypodermis, He $=$ Hexagonal crystal, LU = Long, simple unicellular trichomes, $\mathrm{R}=$ Rhombic crystal, ST = Stomata, arc I, arc II, arc III, and arc IV = Vascular system.

to this genus (i.e., G. bulbifera, G. winitii, G. annamensis, G. laeta, G. marantina, and G. panicoides), and our results are in accordance with those studies. The epidermal cells on both surfaces of all species are four to seven-sided and the length is more than twice the width, which are consistent with Tomlinson ${ }^{23,24}$ and Lakoet ${ }^{26}$. In this study, we did not find cuticle ornamentation on both surfaces, which is different from the study of Lakoet ${ }^{26}$ that reported the cuticle ornamenta- tion was streaked and present on both surfaces in G. laeta, G. marantina, G. panicoides, and G. winitii. The stomata develop on both surfaces, but only infrequently on the adaxial surface. The stomata of most species are tetracytic, which corresponds to the reports by Tomlinson ${ }^{23,24}$ and Lakoet ${ }^{26}$, while pentacytic is found in G. adhaerens (albus bract), G. albiflora var. albiflora, G. annamensis, G. bicolor, G. cambodgensis, G. laeta, G. marantina, G. nuda, G. pendula, G. praecox, G. purpurascens, G. race- 
mosa, G. sessiliflora, G. sherwoodiana, G. siamensis, G. williamsiana, and $G$. winitii and hexacytic stomata are found in G. praecox and G. racemosa, which Tomlinson ${ }^{23,24}$ and Lakoet ${ }^{26}$ did not report. Stomatal densities in $G$. annamensis $\left(10 \pm 3\right.$ per $\left.\mathrm{mm}^{2}\right)$, G. laeta $\left(19 \pm 3\right.$ per $\left.\mathrm{mm}^{2}\right)$, G. marantina $(67 \pm 4$ per $\left.\mathrm{mm}^{2}\right)$, G. panicoides $\left(12 \pm 2\right.$ per $\left.\mathrm{mm}^{2}\right)$, and $G$. winitii $\left(8 \pm 3\right.$ per $\left.\mathrm{mm}^{2}\right)$, on the adaxial surface, differed from Lakoet ${ }^{26}$, who reported the stomata densities found in G. annamensis $\left(4.0 \pm 1.6\right.$ per $\left.\mathrm{mm}^{2}\right)$, G. laeta $\left(25.3 \pm 7.9\right.$ per $\left.\mathrm{mm}^{2}\right)$, G. marantina $(4.6 \pm 1.3$ per $\left.\mathrm{mm}^{2}\right)$, G. panicoides $\left(50.7 \pm 4.7\right.$ per $\left.\mathrm{mm}^{2}\right)$, and G. winitii $\left(11.9 \pm 5.7\right.$ per $\left.\mathrm{mm}^{2}\right)$ on the adaxial surface. The other characteristic of the leaf epidermis was trichomes that are found to be present on both surfaces, except in G. albiflora var. albiflora, G. albiflora var. aurea, G. globulifera, and G. nuda, in which trichomes are not found on both surfaces. The types of trichomes can be divided into four groups as follows: short, simple unicellular trichomes; long, simple unicellular trichomes; glandular trichomes; and long, biseriate trichomes. The latter type has never been reported for the genus Globba in the previous work by Tomlinson ${ }^{23,24}$ and Lakoet ${ }^{26}$. Hence long, biseriate trichomes are recorded for the first time in the genus. Most taxa have cell inclusions, such as oil cell, rhombic, square, and rectangle crystals and silica bodies, which are found on both surfaces, whereas silica sand and hexagonal crystal are found only on the abaxial surface. This result differs from Tomlinson ${ }^{23,24}$ and Lakoet ${ }^{26}$ as they did not find cell inclusions in epidermal cells on both surfaces. Hypodermis in Globba is present on the abaxial surface with only one row, in agreement with the studies of Tomlinson ${ }^{23,24}$ and Lakoet ${ }^{26}$. Rhombic and hexagonal crystals are present in the hypodermis, which is reported here for the first time in the genus. The mesophyll has a separation that is clear between the palisade and spongy regions; all species have bifacial leaves. Most of the studied species have rhombic crystals in the mesophyll. The presence of crystals in the mesophyll in Globba is consistent with Tomlinson ${ }^{23,24}$, but differs from Lakoet ${ }^{26}$ who did not find crystals in the mesophyll. The vascular bundles are collateral and appear in a single series across the leaf blade. Rhombic, rectangle, square, and hexagonal crystals and silica sand are present on the midrib, which differs from Tomlinson $^{23,24}$ and Lakoet ${ }^{26}$ as they did not find rhombic, rectangle, square, and hexagonal crystals and silica sand to be present on the midrib. The shape of the leaf margin in the transverse section can be divided into three groups as follows: taper, curved up, and curved down. The latter type has never been reported for the genus Globba in the previous work by Tomlinson ${ }^{23,24}$ and Lakoet ${ }^{26}$. Hence the shape of leaf margin as being curved up is recorded for the first time in the genus. The outline of the midrib in the transverse section on both surfaces curves to a U-shape, which is consistent with the work of Lakoet ${ }^{26}$, while the adaxial surface curves to be slightly flat in G. globulifera, which differs from Lakoet ${ }^{26}$. The shape of midrib on adaxial surface of some species are V-wider shaped ${ }^{26}$, which differs from the results of this study. Most of the species have long, simple unicellular trichomes on the abaxial surface of the midrib except for $G$. candida and G. siamensis, which have long, simple unicellular trichomes on both surfaces of the midrib. The long, simple unicellular trichomes are reported here for the first time in the genus. Based on the types of vascular system in the midrib proposed by Tomlin$\operatorname{son}^{23}$, the vascular system of the genus Globba is composed of arcs I, II, III, and IV. The latter type has never been reported for the genus Globba in the previous work by Lakoet ${ }^{26}$. The result of the present investigation shows that leaf anatomical characters could be employed to distinguish between species of Globba. In the present study the leaf anatomical features of 21 taxa of Thai Globba are recorded for the first time.

\section{CONCLUSIONS}

Our findings show that the size, shape, exine sculpturing, and types of spine apex of 22 taxa of Thai Globba can be used for grouping in the genus. The pollen characters of all taxa are quite similar in all aspects; hence pollen morphology has low taxonomic value to identify Globba taxa. The only qualitative character that can be used to separate G. panicoides from other taxa is the exine sculpture. Hence using the pollen characters alone does not help in resolving the classification of the genus as they cannot be used to identify all species, but they provide some information for distinguishing some taxa. Leaf anatomical studies have been used successfully to clarify taxonomic status and help in the identification of taxa. The leaf anatomy of 26 taxa of Globba species showed differences in the types of stomata, density of stomata on the abaxial surface, width of subsidiary cell on abaxial surface, types of trichomes, cell inclusion presence or absence in mesophyll, midrib and abaxial surface, number of rows in the intercostal region on abaxial surface, length of guard cell on abaxial surface, hypodermis presence or absence on the abaxial surface of 
1. Hypodermis present on abaxial surface in transverse section of leaf blade

2. Density of stomata on abaxial surface more than 200 per $\mathrm{mm}^{2}$

3. Number of rows in intercostal regions on abaxial surface varies from 10-12 rows

4. Long, biseriate trichomes absent on abaxial surface

4. Long, biseriate trichomes present on abaxial surface

5. Rhombic and hexagonal crystals present on hypodermis

5. Rhombic and hexagonal crystals absent on hypodermis

3. Number of rows in intercostal regions on abaxial surface varies from 6-9 rows

6. Tetracytic stomata present only on adaxial surface

7. Long, simple unicellular trichomes present on abaxial surface in transverse section of leaf blade

7. Long, simple unicellular trichomes absent on abaxial surface in transverse section of leaf blade

6. Tetracytic and pentacytic stomata present on adaxial surface

8. Square crystals present on adaxial surface

8. Square crystals absent on adaxial surface

9. Long and short, simple unicellular trichomes present on adaxial surface

9. Long and short, simple unicellular trichomes absent on adaxial surface

G. sherwoodiana

G. aff. winitii

G. siamensis

G. schomburgkii

G. xantholeuca

G. nuda

G. marantina G. cambodgensis

2. Density of stomata on abaxial surface less than 200 per $\mathrm{mm}^{2}$

10. Long, simple unicellular trichomes present on midrib

11. Width of mesophyll more than 90

11. Width of mesophyll less than $90 \mu \mathrm{m}$

12. Rhombic and hexagonal crystals present on mesophyll

12. Rhombic and hexagonal crystals absent on mesophyll

10. Long, simple unicellular trichomes absent on midrib

13. Length of guard cell on abaxial surface more than $30 \mu \mathrm{m}$

14. Shape of midrib on adaxial surface curved to slightly $f$ at

14. Shape of midrib on adaxial surface curved to U-shaped

15. Length of leaf margin more than 300

15. Length of leaf margin less than $300 \mu \mathrm{m}$

16. Silica sand present on midrib

16. Silica sand absent on midrib

13. Length of guard cell on abaxial surface less than $30 \mu \mathrm{m}$

17. Hexacytic stomata present on abaxial surface

17. Hexacytic stomata absent on abaxial surface
G. adhaerens (albus bract)

G. racemosa

G. laeta

G. globulifera

G. william siana

G. bicolor

G. pendula

G. preacox

G. purpurascens

1. Hypodermis absent on abaxial surface in transverse section of leaf blade

18. Leaf margin taper

19. Rhombic crystals present on adaxial surface

19. Rhombic crystals absent on adaxial surface

G. albiflora var. albiflora

18. Leaf margin curved

20. Leaf margin curved up

20. Leaf margin curved down

21. Width of subsidiary cell on abaxial surface longer than adaxial surface

21. Width of subsidiary cell on abaxial surface shorter than adaxial surface

22. Glandular trichomes present on abaxial surface

23. Short, simple unicellular trichomes present on adaxial surface

23. Short, simple unicellular trichomes absent on adaxial surface

G. adhaerens (violaceus bract)

22. Glandular trichomes absent on abaxial surface

24. Vascular bundle type arc I, arc II and arc III

24. Vascular bundle type arc I and arc II

25. Long, simple unicellular trichomes present on midrib

25. Long, simple unicellular trichomes absent on midrib

G. annamensis

G. candida

G. reflexa

G. sesiliflora

G. panicoides

G. albiflora var. aurea

Fig. 6 Identification key based on leaf anatomy features for taxa studied.

the lamina, width of the mesophyll layer, shape of midrib, types of vascular system, and shape of leaf margins. Hence a key to the taxa based on leaf anatomy was constructed (Fig. 6).

Acknowledgements: We would like to thank the Human Resource Development in Science Project (Science
Achievement Scholarship of Thailand, SAST) for financial support during the study. We are grateful to the Department of Biology, Faculty of Science, Mahasarakham University, Thailand, for providing laboratory facilities. We wish to thank Dr Jolyon Dodgson for his review and correction of the manuscript. We also thank the Plant Taxonomy Laboratory's students for field support. 


\section{REFERENCES}

1. Williams KJ, Kress WJ, Manos PS (2004) The phylogeny, evolution, and classification of the genus Globba and tribe Globbeae (Zingiberaceae): appendages do matter. Am J Bot 91, 100-14.

2. Larsen K, Larsen SS (2006) Gingers of Thailand, Queen Sirikit Botanic Garden, Chiang Mai.

3. Takano A, Okada H (2003) Taxonomy of Globba (Zingiberaceae) in Sumatra, Indonesia. Syst Bot 28, 524-46.

4. Schumann K (1904) Zingiberaceae. In: Engler A (ed) Das Pflanzenreich, IV. 46, Leipzig, W Engelmann, pp 1-458.

5. Larsen K (1996) A Preliminary checklist of the Zingiberaceae of Thailand. Thai Forest Bull (Bot) 24, $35-49$.

6. Kress WJ, DeFilipps RA, Farr E, Kyi DYY (2003) A Checklist of the Trees, Shrubs, Herbs, and Climbers of Myanmar, Contributions from the US National Herbarium, Smithsonian Institution Press, DC.

7. Srisanga P, Wongpakam S, Kamkuan W, Pekthong T, Tovaranonte J, Yaso T, Nontachyapoom S (2011) Ethnobotany of Akha in Huay Yuak Pa So village, Mae Fah Luang district and Ban Mai Patthana village, Mae Suai district, Chaing Rai province. Thai J Bot 3, 93-114.

8. Saensouk S, Saensouk P, Pasorn P, Chantaranothaic P (2016) Diversity and uses of Zingiberaceae in Nam Nao National Park, Chaiyaphum and Phetchabun provinces, Thailand, with a new record for Thailand. Agr Nat Resour 50, 445-53.

9. Nairs PKK (1970) Pollen Morphology of Angiosperms: A Historical and Phylogenetic Study, Barnes \& Noble, New York.

10. Larsen K, Lock JM, Maas H, Maas PJM (1998) Zingiberaceae. In: Kubitzki $\mathrm{K}$ (ed) The Families and Genera of Vascular Plants, Springer-Verlag, Berlin, pp 474-95.

11. Saensouk S (2006) Taxonomy and biology of the genus Alpinia Robx. (Zingiberaceae) in Thailand. $\mathrm{PhD}$ thesis, Khon Kaen Univ.

12. Triboun P (2006) Biogeography and biodiversity of the genus Zingiber in Thailand. $\mathrm{PhD}$ thesis, Khon Kaen Univ.

13. Saensouk P, Chahtaranothai P, Theerakulpisut P (2009) Pollen morphology of the genus Cornukaempferia (Zingiberaceae) in Thailand. J Systemat Evol 47, 139-43.

14. Chen J, Xia NH (2011) Pollen morphology of Chinese Curcuma L. and Boesenbergia Kuntz (Zingiberaceae): Taxonomic implications. Flora 206, 458-67.

15. Saensouk P, Theerakulpisut P, Thammathaworn A, Saensouk S, Maknoi C, Kohkaew P (2015) Pollen morphology of the genus Curcuma (Zingiberaceae) in Northeastern Thailand. Sci Asia 41, 87-92.

16. Theilade I, Maersk-Moller ML, Theilade J, Larsen K
(1993) Pollen morphology and structure of Zingiber (Zingiberaceae). Grana 32, 338-42.

17. Liang YH (1988) Pollen morphology of the family Zingiberaceae in China-pollen types and their significance in the taxonomy. Acta Phytotax Sin 26, 265-86 [in Chinese].

18. Chen ZY (1989) Evolutionary patterns in cytology and pollen structure of Asian Zingiberaceae. In: Holm-Nielsen LB, Nielsen IC, Balslev H (eds) Tropical Forests: Botanical Dynamics, Speciation \& Diversity, Academic Press, pp 185-91.

19. Mangaly JK, Nayar J (1990) Palynology of South Indian Zingiberaceae. Bot J Linn Soc 103, 351-66.

20. Kaewsri W, Paisooksantivatana Y (2007) Morphology and palynology of Amomum Roxb. in Thailand. Gard Bull Singapore 59, 105-12.

21. Syamsuardi S, Mansyurdin M, Nurainas N, Susanti $\mathrm{T}$ (2010) Variasi morfologi polen genus Globba (Zingiberaceae) di Sumatra Barat. Berk Penel Hayati 16, 89-94 [in Indonesian].

22. Jones SE, Pearce KG (2015) A pollen morphology study from the Kelabit Highlands of Sarawak, Malaysian Borneo. Palynology 39, 150-204.

23. Tomlinson PB (1956) Studies in the systematic anatomy of the Zingiberaceae. Bot J Linn Soc 55, 547-92.

24. Tomlinson PB (1969) Anatomy of the Monocotyledons III Commelinales-Zingiberaceae, Clarendon Press, Oxford.

25. Hussin KH, Seng TC, Ibrahim H, Gen QW, Ping JL, Nian L (2000) Comparative leaf anatomy of Alpinia Roxb. species (Zingiberaceae) from Thailand. Bot $J$ Linn Soc 133, 161-80.

26. Lakoet C (2004) Comparative anatomy of Zingiberaceae in Phu Phan National Park. MSc thesis, Khon Kaen Univ.

27. Stuessy TF (1990) Plant Taxonomy: the Systematic Evaluation of Comparative Data, Columbia Univ Press, New York.

28. Troia A, Raimondo FM, Castellano G, Spadaro V (2012) Morphological, karyological and taxonomic remarks on Ferulago nodosa (L.) Boiss. (Apiaceae). Plant Biosyst 146, 330-7.

29. Ceter T, Ekici M, Pinar NM, Ozbek F (2013) Pollen morphology of Astragalus L. section Hololeuce Bunge (Fabaceae) in Turkey. Acta Bot Gallica 160, 43-52.

30. Erdtman G (1969) Pollen Morphology and Plant Taxonomy: Angiosperms (an Introduction to Palynology I), Heffner Publishing, London.

31. Punt W, Hoen PP, Blackmore S, Nilsson S, Le Thomas A (2007) Glossary of pollen and spore terminology. Rev Palaeobot Palynol 143, 1-81.

32. Thammathaworn A (1995) Handbook for Permanent Slides of Plant Tissue by Paraffin Method, Department of Biology, Faculty of Science, Khon Kaen Univ [in Thai]. 